


\section{Historic, archived document}

Do not assume content reflects current scientific knowledge, policies, or practices. 


$$
\text { EX LIBRIS }
$$

M. Y. NUTTONSON 


\section{Living \\ and Forest Lands}

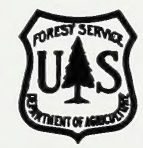

Prepared in the Division of Information and Education, Forest Service, as a Guide for Study Groups Especially Interested in the Social and Economic Aspects of Forests and Forestry 



\section{CONTENTS}

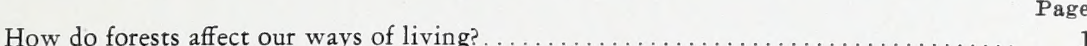

Discussion points

Developing interest . . . . . . . . . . . . . . . . . . . . . . . .

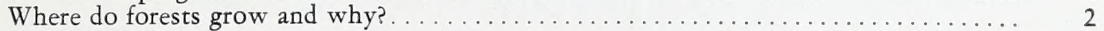

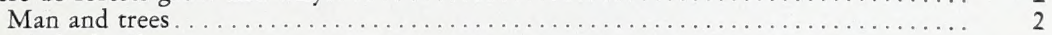

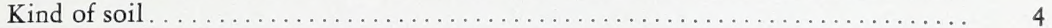

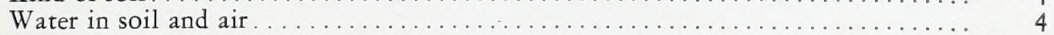

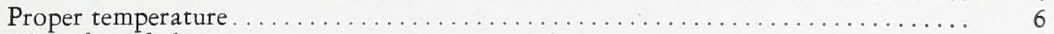

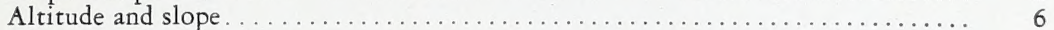

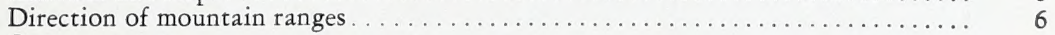

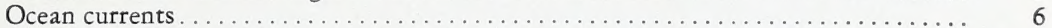

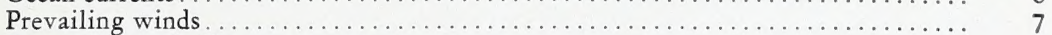

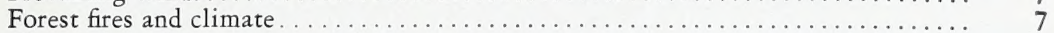

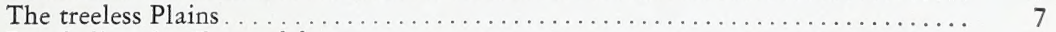

Local climatic effects of forests . . . . . . . . . . . .

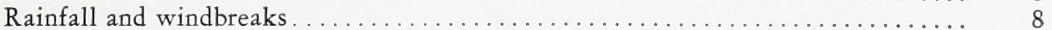

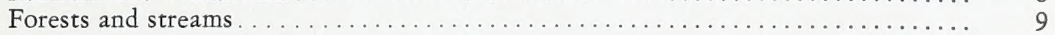

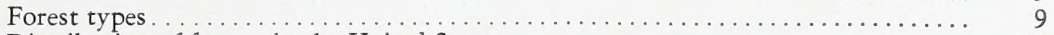

Distribution of forests in the United States . . . . . . . . . . . . . . . . 11

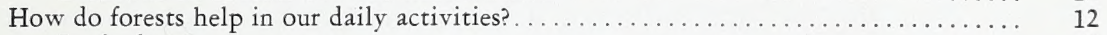

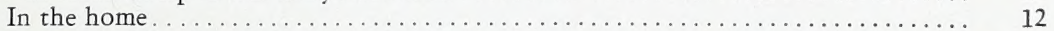

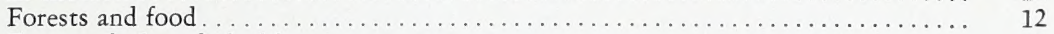

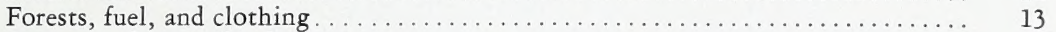

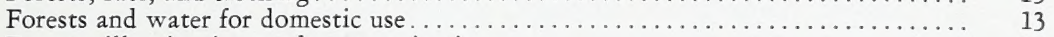

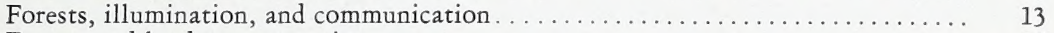

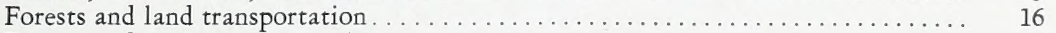

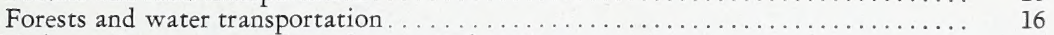

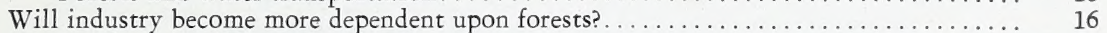

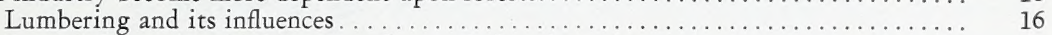

Forests determine the location of many industries . . . . . . . . . . . . . . 17

Different woods for different industries . . . . . . . . . . . . . . . . . . . 17

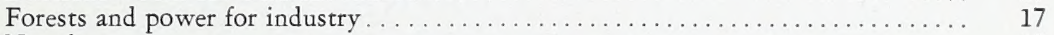

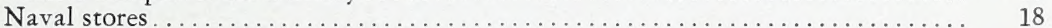

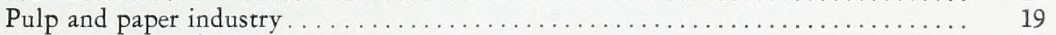

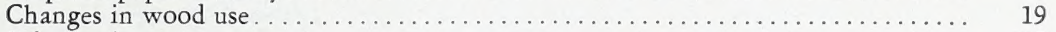

Substitution not necessary . . . . . . . . . . . . . . . . . . . . . . . . 19

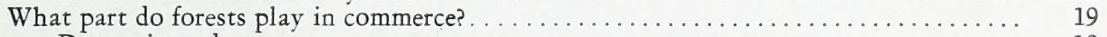

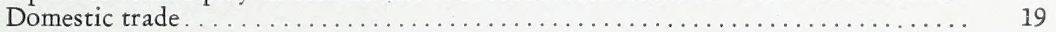

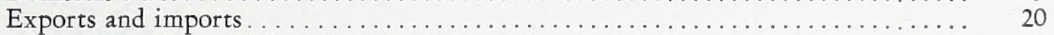

How do forests help provide gainful employment? . . . . . . . . . . . . . . . . 20

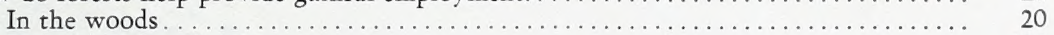

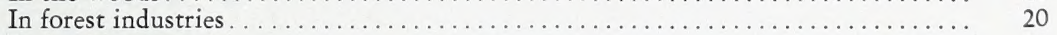

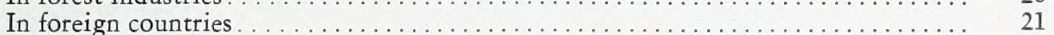

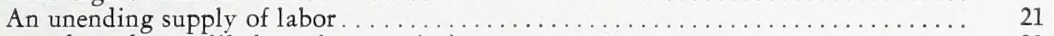

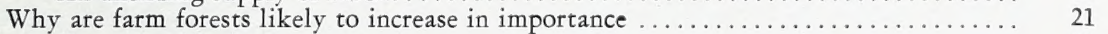

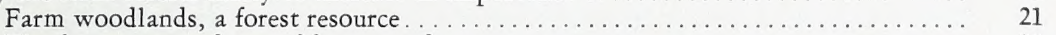

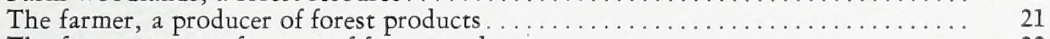

The farmer, a manufacturer of forest products $\ldots \ldots \ldots \ldots \ldots \ldots \ldots \ldots \ldots \ldots \ldots \ldots .22$

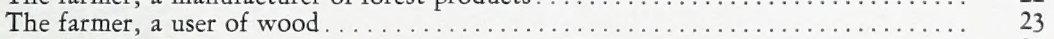

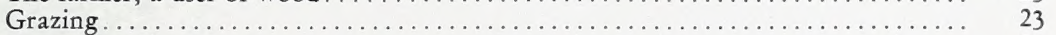

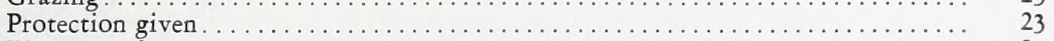

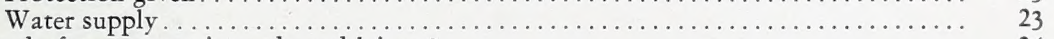

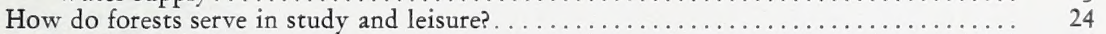

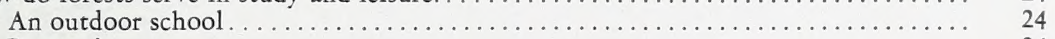

Recreation . . . . . . . . .

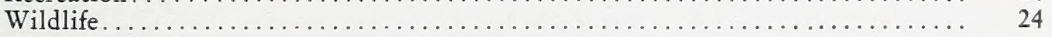




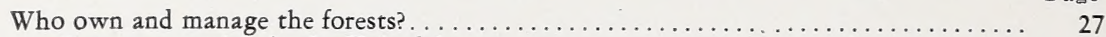

Forest ownership in the United States . . . . . . . . . . . . . . . . . 27

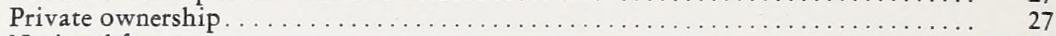

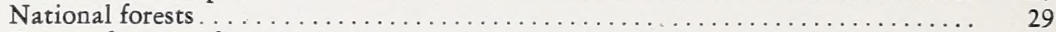

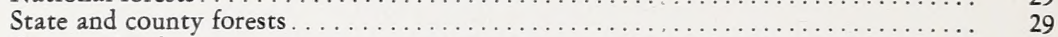

Community forests . . . . . . . . . . . . . . . . . . . . . . . . 29

Commercial forest land . . . . . . . . . . . . . . . . . . . . . . . . . . 29

Noncommercial forest land . . . . . . . . . . . . . . . . . . . . . . 29

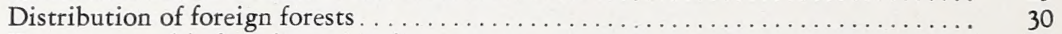

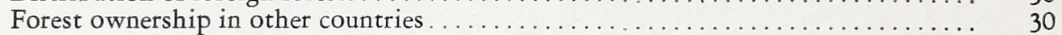

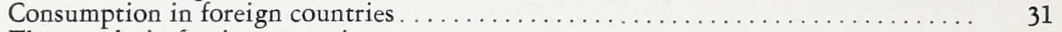

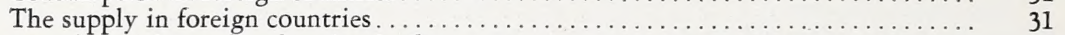

How can forests be used and maintained? . . . . . . . . . . . . . . 33

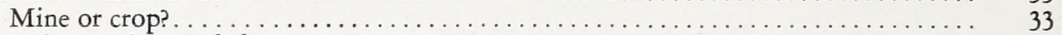

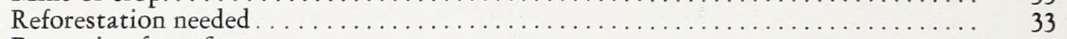

Protection from fire . . . . . . . . . . . . . . . . . . . . 34

Protection for the attractiveness of the forest $\ldots \ldots \ldots \ldots \ldots \ldots \ldots \ldots \ldots \ldots \ldots$

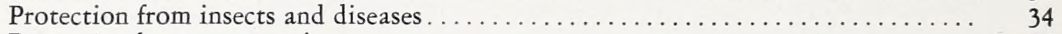

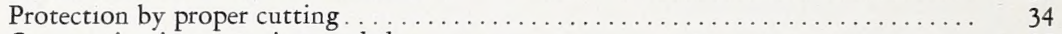

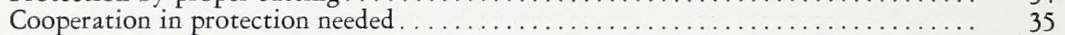

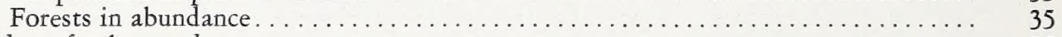

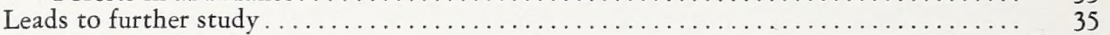

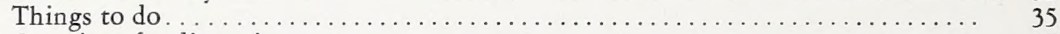

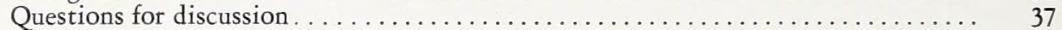

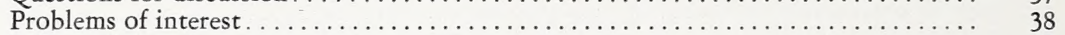

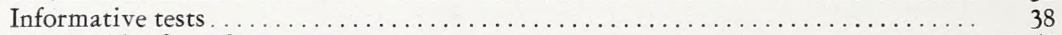

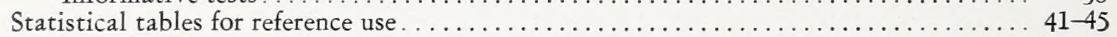

Issued September 1940; slightly revised July 1941, March 1951 


\title{
Living and Forest Lands
}

\author{
How Do Forests Affect Our Ways of Living?
}

Living in lowlands produces habits and customs different from those prevailing in highlands. So also, people living in or near forests develop certain characteristic activities not evident among inhabitants of treeless plains. Even distant forests exert an influence by supplying raw materials, protecting the sources of water supply, and in other indirect ways.

The home sites of more than one-third of the people of the United States occupy only about one five-hundredths of the total land area. Forests, farm and range lands, lakes, and streams occupy the big spaces of our country upon which urban industrial centers depend for natural resources that furnish necessities in the lives of city dwellers.

The rural dwellers who are scattered over most of the land area derive a more direct benefit from the natural resources than do the people of towns and cities. Although the people on the land use some of the resources themselves, equally important benefits result from production of commodities for others. Those engaged in forestry, lumbering, turpentine operations, and many other activities derive their entire livelihood from the forest.

Wood, the primary raw material of the forest, is an everyday necessity contributing to the comfort, convenience, health, pleasure, and recreation of mankind. Chairs, desks, tables, pencils, rulers, paper, rubber, and many other things in constant use have their origin in the forest. Adults as well as children wear rayon garments made from wood cellulose. Food products and gift articles are wrapped in cellophane, also produced from wood. Nuts and maple sugar are delicacies that come from the forest. Contributions of the forest to our daily life may be found in our homes, schools, libraries, churches, parks, and playgrounds.

Because of the many contributions of the forest to the welfare of both individuals and nations, forest conservation is of intense interest to many study groups in the United States. It is the design of this publication to serve as a guide to such groups interested especially in the social and economic aspects of forests and forestry. To this end questions and certain informative tests have been included to be used in stimulating intelligent discussion of and thinking about the principles of conservation.

Discussion points. - Study discussions of these social aspects of forests and forestry may be designed to bring out various points. Among these may be:

1. Forests, like men, adapt themselves to an environment.

2. Forests affect our daily activities.

3. Forest raw materials are necessary in the day's work and in industry.

4. Forest products are the basis of much commerce.

5. Farm woodlands and windbreaks are a part of a balanced agriculture.

6 . Forests have recreational and educational values. 
7. Forests in public ownership are generally better managed than those in private ownership.

8. Forests can be used and kept continuously productive.

Developing interest.-Interest in discussions may be aroused in various ways. The following are suggested:

1. Talk about the kinds of trees in the community. Lead the talk to a consideration of climate as a factor determining where forests grow and where different kinds of forests flourish. Bring out the point that conditions good for tree growth are usually favorable for habitation of a region by man.

2. Ask someone what kind of wood is used in making baseball bats. Does it make any difference where this wood grows? Ask whether a substitute for wood for ball bats would be satisfactory. If so, what might it be? Why is there a difference between ash grown in New York and that grown in Kentucky?

Ash grown in New York and Pennsylvania is the principal wood used in making bats for the big baseball leagues. The heavier Ohio and Kentucky ash will not make up into bats light enough for the average batter, who wants one that weighs not over 30 ounces.

The ash is cured in a shed for about 2 years before it is turned into bats, because it has to be thoroughly dried. If wet, it is too heavy and lifeless. The factory is fortunate if 30 percent of the ash in a carload is suitable for the best bats. The lower grade 70 percent is made into the cheaper bats.

3. Discuss the ways in which the presence or absence of forests in the county affects the way the people live.

4. Discuss the following statements, using a map of the forests of the United States:

a. Thousands of towns and cities depend on forests for their domestic water supplies.

b. Eighty-five percent of the water used to irrigate western farms comes from forested watersheds.

c. More than one-third of the water-power resources of the country lie within the national forests.

5. Raise the following questions for discussion:

a. Who makes the most use of the forest, the uncivilized or the civilized man?

b. If our forests were all destroyed, what forest benefit would be most missed?

6. Visit some wood-using industry or a lumberyard. Trace the wood supply by various transportation methods and routes to its various sources.

7. Have someone write to the State forester for information about forest conditions in the State.

8. Have someone write for information on national forests in the State. (See p. 36 for the address of your regional forester.)

\section{Where Do Forests Grow and Why?}

Man and trees.-Much the same conditions of moisture, temperature, and soil determine where the greatest number of people and the greatest number of trees may live. Regions of dense populations are often those where 
dense forests once stood and the sparsely populated areas are often associated with arid plains. Where much forest remains, however, population is usually sparse.

FIGURE 1.-How could a person tell from an airplane whether he was passing over a softwood or hardwood forest? $A$, Typical softwood or coniferous forest; $B$, typical hardwood or deciduous forest.
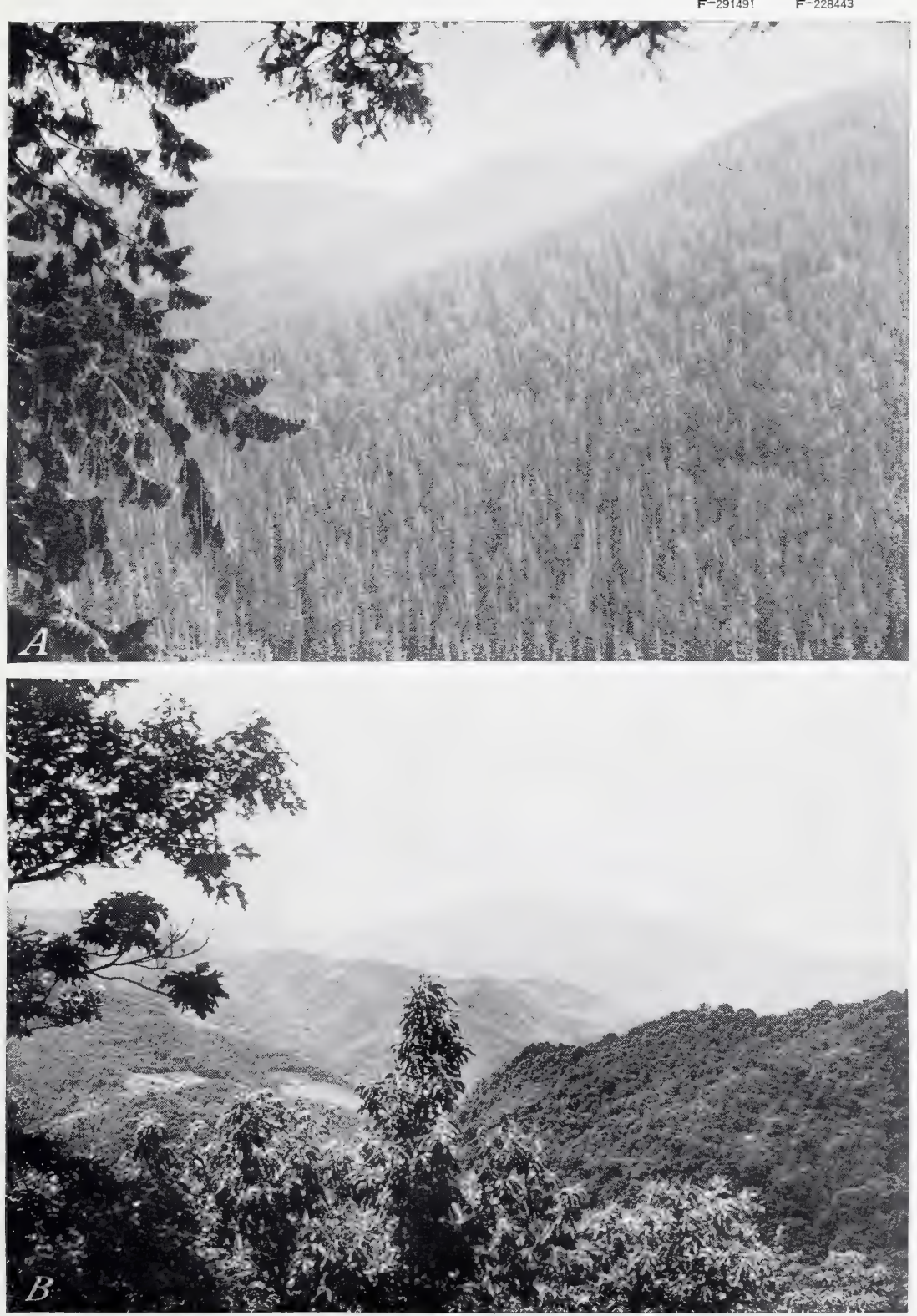
Primitive people living within forests have certain characteristics that result from their surroundings-they may live in houses in treetops or make abundant use of poles in building shelters; they eat largely fruit, nuts, fish, and game; they travel usually by boat or on foot. The forest has kept them from wandering, from contact with other people, and hence has retarded their progress. The fact that the forest provides them with protection, food, and shelter with little effort on their part may also partly explain their lack of progress.

When man progressed to a point where the forest no longer dominated him, increasing use of forest resources became necessary for his further progress. Access to forests has been an important influence in the development of leading civilizations.

People have adjusted their modes of life to different climates. So have trees. Trees may be divided into two great classes-the conifers, which include such species as the pines, spruces, cedars, and firs; and the broad leares, which include such species as the oak, maple, ash, hickory, elm, and walnut. The conifers, or those we commonly call evergreens, live mainly in the colder, drier parts of the world. The broadleaf species prefer the warmer, more humid climates. Some of those in tropical regions are evergreen. The two classes of trees are also known as softwoods and hardwoods (fig. 1).

There are no hard and fast distinctions between the two classes of trees (table 1, p. 41). Exceptions to most points may be noted. Holly and live oak are evergreen broadleaf trees; larch and cypress are deciduous conifers. Either class sometimes may be found growing under conditions best adapted to the other. There is an abundance of pine in the South and conifers and broadleaf species often grow in the same stand. Longleaf pine, a conifer or softwood, is more dense or harder than yellow poplar, a broadleaf or hardwood.

Kind of soil.- Trees are sensitive to differences in soil. Even slight variations in texture and fertility cause differences in forest growth.

Soil furnishes anchorage, water, and mineral food. It therefore affects a tree's rate of growth, length of life, form, quality of wood, capacity to endure shade, the quantity of seed produced, and its vield of wood and other products.

Some kinds of trees are most commonly found on clav soils; others on sandy soils. Some need deep fertile soils; others will grow on almost bare rock. White oak, maple, rellow poplar, and other important hardwoods do best on a moist soil rich in organic matter. Blackjack oak, jack pine, persimmon, and sassafras, do well on infertile soils. An experienced woodsman can tell much about the soil by the trees growing on it.

$W$ ater in soil and air.-Where the annual rainfall is below 20 inches per year, under natural conditions few trees will grow in the region. They will be found along water courses or in low places where the amount of available moisture is greater. Trees need water to dissolve the plant food in the soil, and to use in making starch. They also need water to circulate their food and to cool them in the summer.

A certain amount of moisture in the atmosphere is also necessary to tree growth. Some kinds of trees need more than others. The atmospheric moisture affects not only the amount of local rainfall, but also determines the amount of water transpired or given off by the leaves, which is one of the reasons relatively few kinds of trees will grow in areas of high and dry winds. 


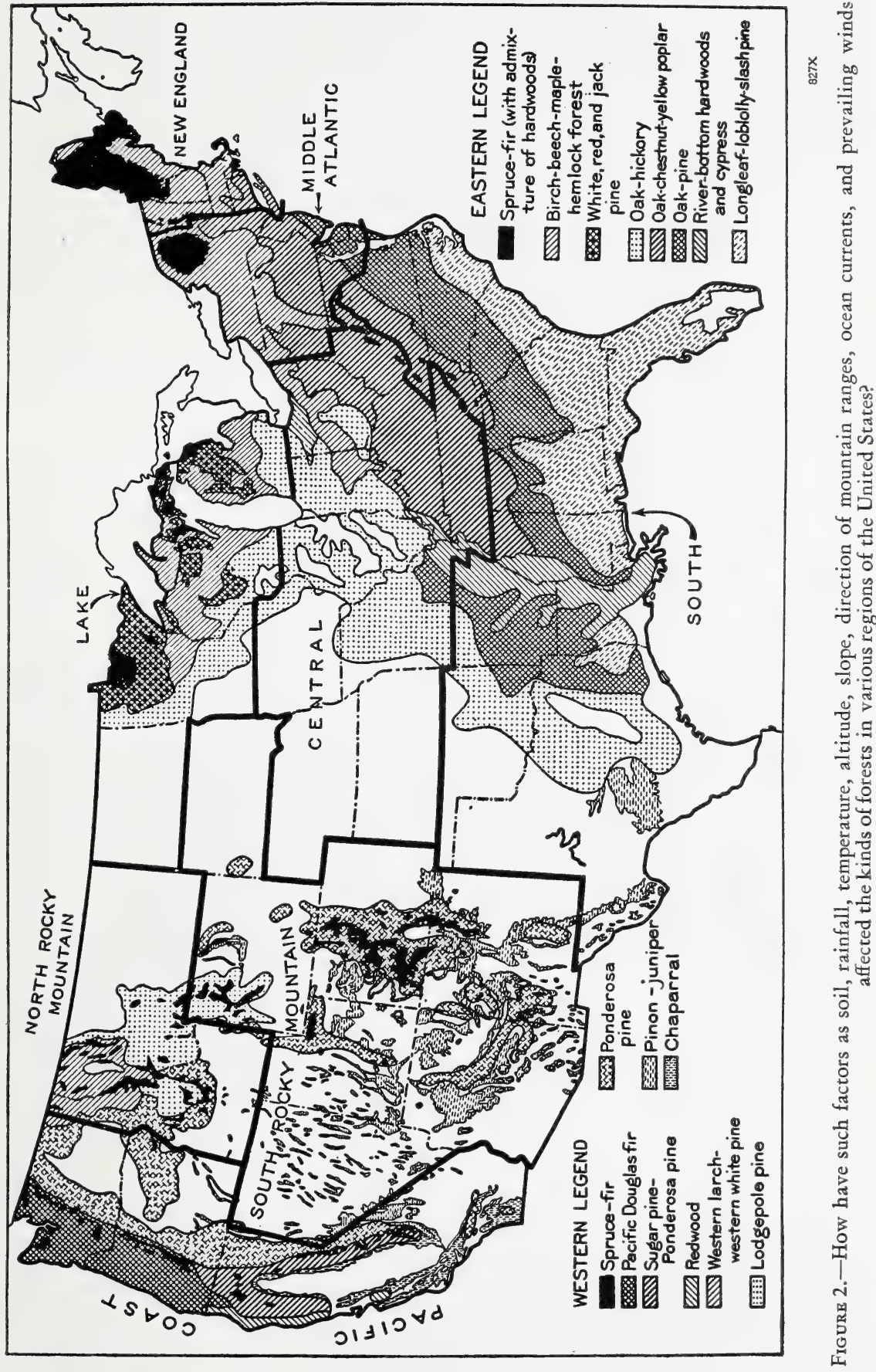


In general, the conifers need less soil and atmospheric moisture than do the broadleaf trees; for that reason conifers are the main species in the drier regions and broad leaves in more humid regions.

Proper temperature.- Some species of plants and animals can live with little heat; others require much. Some kinds of trees can grow in central Alaska, whereas others require the heat of the Torrid Zone. The conifers usually occupy the colder regions while the hardwoods occupy the warm regions but some kinds of conifers live in the southern parts of the United States and some broadleaf trees live in Canada.

Apparently there are certain critical temperatures above which and below which a tree cannot survive during its growing period. Some tropical varieties are killed by temperatures of $41^{\circ} \mathrm{F}$. Length of growing season is another factor determining the kinds of trees that grow in a region.

Strains of the same species become adapted to different temperatures. If seed collected from black oak in Oklahoma is planted in Connecticut, the seedlings will rarely live through the first winter, although black oak is native to Connecticut.

Northern varieties of trees encounter a southern limit beyond which they cannot survive. Although they gain some advantages in increased temperature and often increased moisture, other things interfere with their growth. The absence of a winter rest period required by some varieties may be the limiting factor. Others produce infertile seed even though they may grow south of the area to which they are adapted. If nothing else hinders them, competition with the trees that are at home in the southern climate crowds out the northern trees (fig. 2).

Altitude and slope.-The northern varieties of trees may extend southward by occupying the higher altitudes and the northern slopes. The northern forest region typical of the New England and northern Lake States, for example, extends as far south as northern Georgia by following the colder temperatures of the Appalachians at an altitude of about 2,000 feet.

The temperature on the peaks of some of the higher mountains is so low trees cannot live there. The upper limit of tree growth on the mountainside is called the timber line. This line becomes established at lower levels toward the poles and at higher levels in warmer climates.

Direction of mountain ranges.-Europe has only about 100 species of trees. North America has more than 800 native species. The explanation: Generally the mountain ranges of Europe run east and west and those of North America north and south. When the glaciers moved southward, the preglacial forests north of the European mountains were buried. Only a few species were able to cross these barriers to the south and back again because of the cold temperature of the high altitudes. In North America without such barriers many of the northern trees moved southward fast enough to keep ahead of the glaciers, if they were not already distributed to the south. It would be only natural for them to regain their lost territory as the ice packs receded to the north, especially since they had no higher altitude to cross than was suited to their temperature needs.

Ocean currents. - Tree growth extends as far as $70^{\circ}$ north latitude on the coast of Alaska because of the warming influence of the Japan current. On the eastern side of Canada tree growth extends only to about $50^{\circ}$ north latitude because there are no warming ocean currents. The southern forest, typical of the Gulf States, extends as far north as Maryland along the lower lands close enough to the coast to be influenced by the tempering effect of the ocean. 
Prevailing winds.--The effects of bodies of water and ocean currents, latitude, altitude, and direction of slope are combined into a forest environment by the prevailing winds. They may bring abundant rainfall warmed by an ocean current, as on the Pacific slopes where the giant redwoods and Douglas fir are produced, or they may be so hot and dry that only the the mesquites and piñon pine may survive, or even a desert is produced.

Forest fires and climate. - It is altogether probable that early forest fires have had much to do with the kind of trees now growing in an area. The same things that determine where trees will grow also contribute to or alleviate the danger of forest fires. Frequent rains, of course, are natural checks on fires. Forests of high altitudes, north slopes, and cold climates generally are not as readily ignited as are those of low altitudes, south slopes, and warm climates. Fire is a threat, however, whenever any forest is dry.

Within a region lightning fires are more numerous on higher ground than on lower ground.

The steeper a slope, the faster fire will burn because the fuel is in more direct line with the upward movement of heat, gases, and flames. Wind is the main factor in the rate of spread of a forest fire and the greater the wind velocity, the greater is the difficulty of controlling the fire.

The season of forest fires in different parts of the United States varies largely with moisture conditions. In the South the most damage is done in December, January, and February because those months have the least rainfall and much of the undergrowth of shrubs and grass in the forest is dormant and dry. In the Southwest spring and summer form an almost unbroken fire season because of the lack of rainfall. In the Northwest summer is the dry period and therefore the season of most forest fires. Lightning storms at this time of year also contribute to the summer fire hazard in these regions. In the Lake States forest fires are most common in the late summer and early fall when rains are infrequent. In the Middle Atlantic States forest fires are most common in spring and fall. The New England States have comparatively few forest fires because of year-round distribution of rainfall. The Central States, or hardwood region, have the most fires in the spring when the fallen leaves have settled and dried.

The kind of forest fires differs mainly with the species of trees. Crown fires, which burn the tops of the trees, are rare in hardwood forests, except in the dwarf hardwoods or chaparral of California. The firs, spruces, hemlocks, and northern pines are very susceptible to crown fires. The southern pines, except the sand pine of Florida, rarely support a crown fire, because they are not so inflammable as are northern varieties and the stands are much more open. Surface fires are closely associated with the southern conifers, and with hardwood areas.

The treeless Plains.-Many have tried to explain why trees do not grow naturally on the Great Plains. In this region, except for fringes of trees along the streams and on a few mountaintops cool enough to condense some moisture from the passing winds, the land is treeless with seemingly endless stretches of grasses, sagebrush, or bare soil. A combination of factors rather than any one factor may be the cause of this condition. However, trees along streams and the forests on the few mountains in the area would seem to indicate that lack of rainfall is the major obstacle to tree growth. It appears also that the extremes of heat and cold and the periodic droughts are important reasons why the Great Plains are covered with grasses instead of trees. 
Man has been able to produce trees where Nature did not see fit to grow them. By using proper cultural methods-such as tillage of the soil before planting to kill grass and weeds and to store moisture, planting only the best seedlings of species adapted to the climate, cultivation for a few years to prevent loss of water from the soil, and protection from livestock and jack rabbits - the Prairie States forestry project in 1939 had about 90,000,000 trees growing in field windbreaks on farms in the prairie-Plains region (fig.3). In the few seasons since they had been planted many of these trees had made faster growth than similar plantings in forest regions.

Local climatic effects of forests. - Limited studies made tend to show measurable differences in certain climatic factors, such as wind velocity and temperature, traceable to the presence of forests. Most scientists are of the opinion that such influence is limited to the forest areas or to very short distances beyond the forest borders. The horizontal extent of windbreak influence leeward is held to be about 20 times the height of the trees. Such influence cannot be expected to change the climatic factors over large and remote areas.

Rainfall and windbreaks.-Forests are a result rather than a cause of rainfall. Although trees may be grown in much of the Great Plains region if given careful attention, the possibility of affecting rainfall by tree planting is remote. These facts have been recognized in the Prairie States forestry project. The primary purpose in the tree-planting work of this undertaking has been to provide the prairie-Plains region with some of the beneficial influences of forests, not to change climate.

Windbreaks should be grown for what it has been proved they can do; namely, check wind velocity within the limited area of their influence; protect growing crops from hot winds; prevent soil from blowing; protect buildings, livestock, and man from strong winds, both hot and cold; attract birds; supply posts, poles, and fuel (fig. 4). The windbreak also

Figure 3.-Field windbreak on the Great Plains. How can man insure the success of tree plantings in areas where favorable conditions for their growth are lacking?

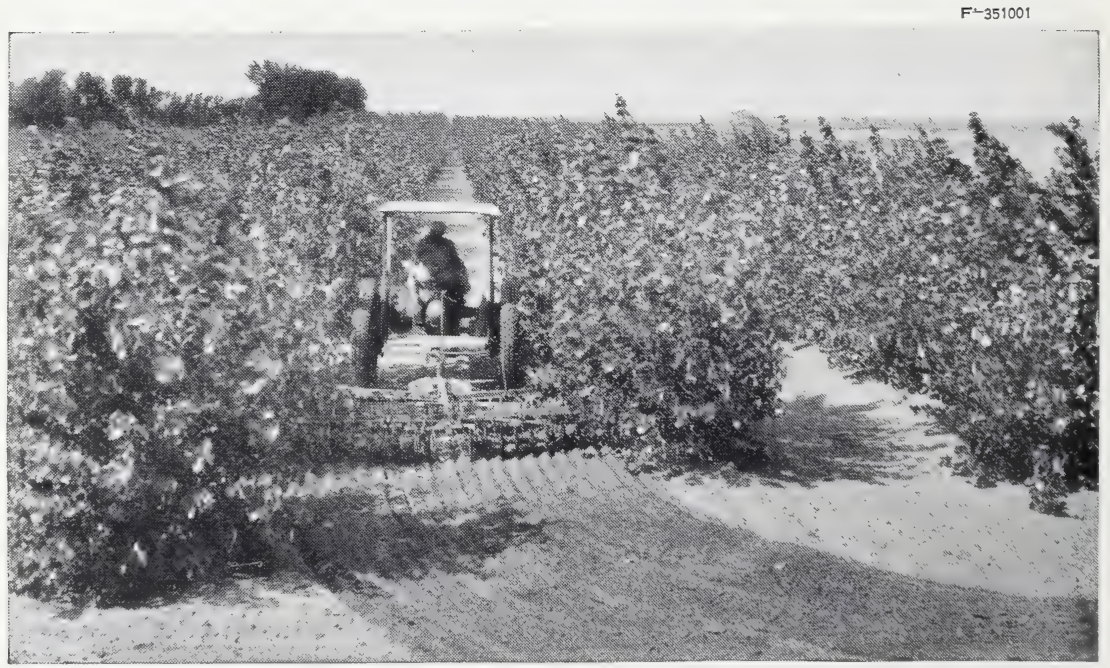




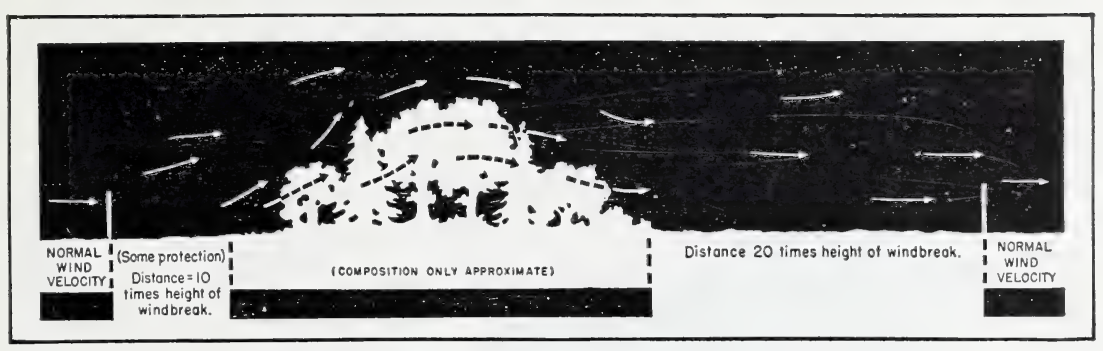

FIGURE 4.-How and to what extent do field windbreaks affect the conditions within an area?

contributes to an improved appearance of farmsteads and the landscape and to more agreeable living conditions generally.

Forests and streams. - The close relation of forests and rivers appears when a few common observations are made. The force of rain falling in the forest is broken by the leaves and branches of the trees. The water reaches a soil covering of fallen leaves, small plants, and twigs if this covering has not been destroyed by fire. Much of the water is absorbed as by a sponge or held temporarily as if by millions of small dams. The forest thus checks rapid run-off of the water and the accumulation of silt in streams.

The forest has other important functions to perform with water. The shade of the trees protects the ground from direct sunlight that hastens evaporation of the water stored in leaf litter and soil. The trees also protect this stored water from winds that would pick up much of it. Snow melts later in the shade than in the open. The forest thus contributes to the steady flow of streams.

Water seeping through the spongy forest floor is clean, and the soil remains porous because there is little sediment to plug the natural runways. Some of the water trickles downward through subterranean channels to find outlets in springs or through seepage at lower levels and thus helps keep the rivers flowing when there is no rain. Much of it may find a way into underground reservoirs beneath lands far removed from the forests, thus helping to maintain the level of their water table. And some of the water is used by the trees and is released through the roots, trunk, branches, and leaves. The forest soil in various ways is thus partly emptied of its water so that when the next rain comes it can readily absorb more water and prevent excessive run-off.

A relief map of the United States shows a network of rivers and streams. Many of these rivers flow out of the great reservoir of forest land. Nearly three-fourths of the forest area in the 17 drainage basins of the United States exerts a moderate to major influence on the protection of soil from erosion, in the reduction of rapid run-off, and in moderating floods (fig. 5). The evaporation of water from the leaves also increases the humidity of the air in the immediate locality.

Forest types.-Forests of the world are of three main types: Coniferous, temperate hardwood, and tropical hardwood. Coniferous forests occupy more than one-third of the forest area of the world, temperate hardwoods occupy one-sixth, and tropical hardwoods nearly one-half. An important fact to remember in this connection is that 95 percent of the coniferous forests, upon which the world chiefly depends for its wood construction, 


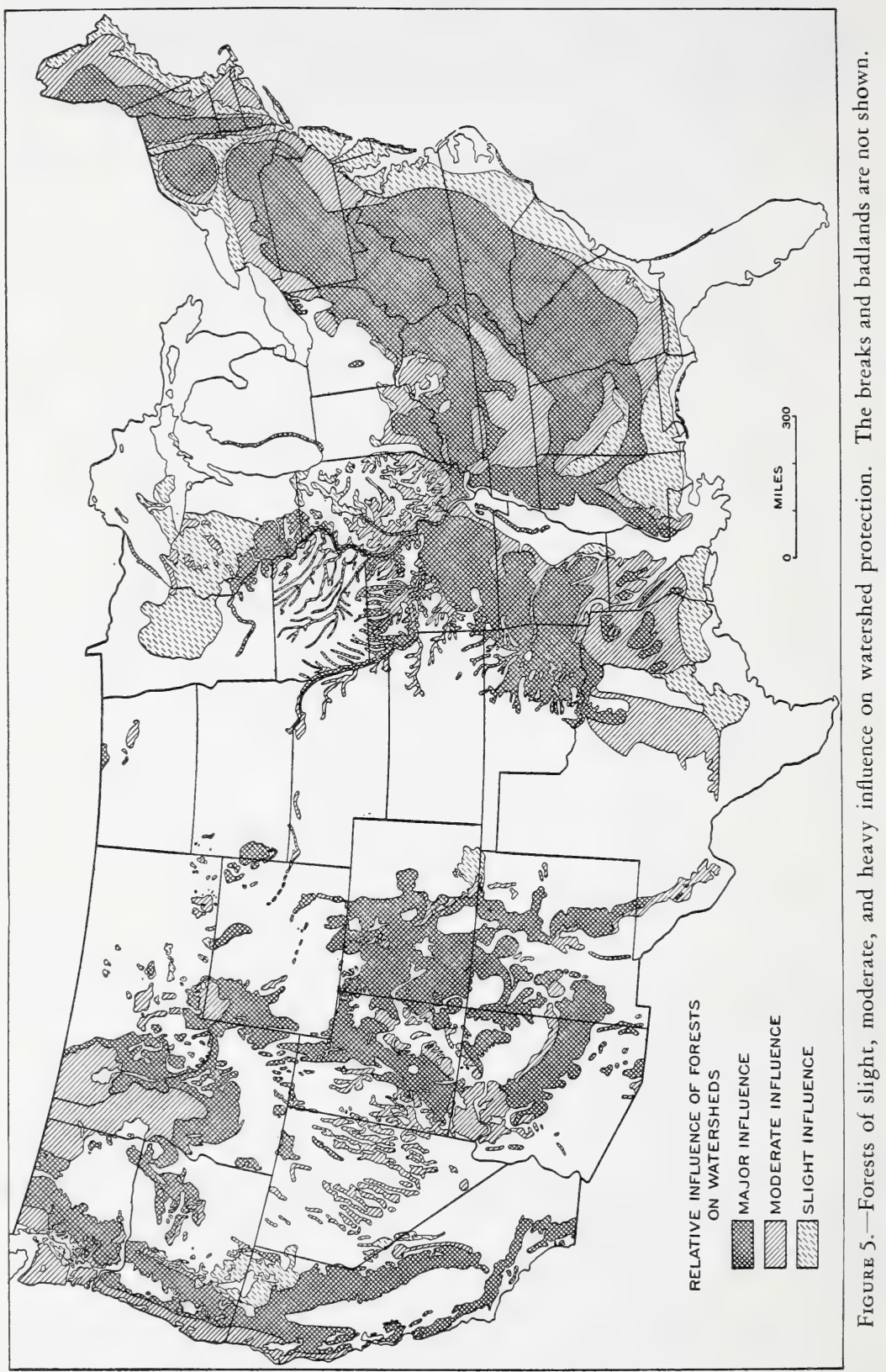




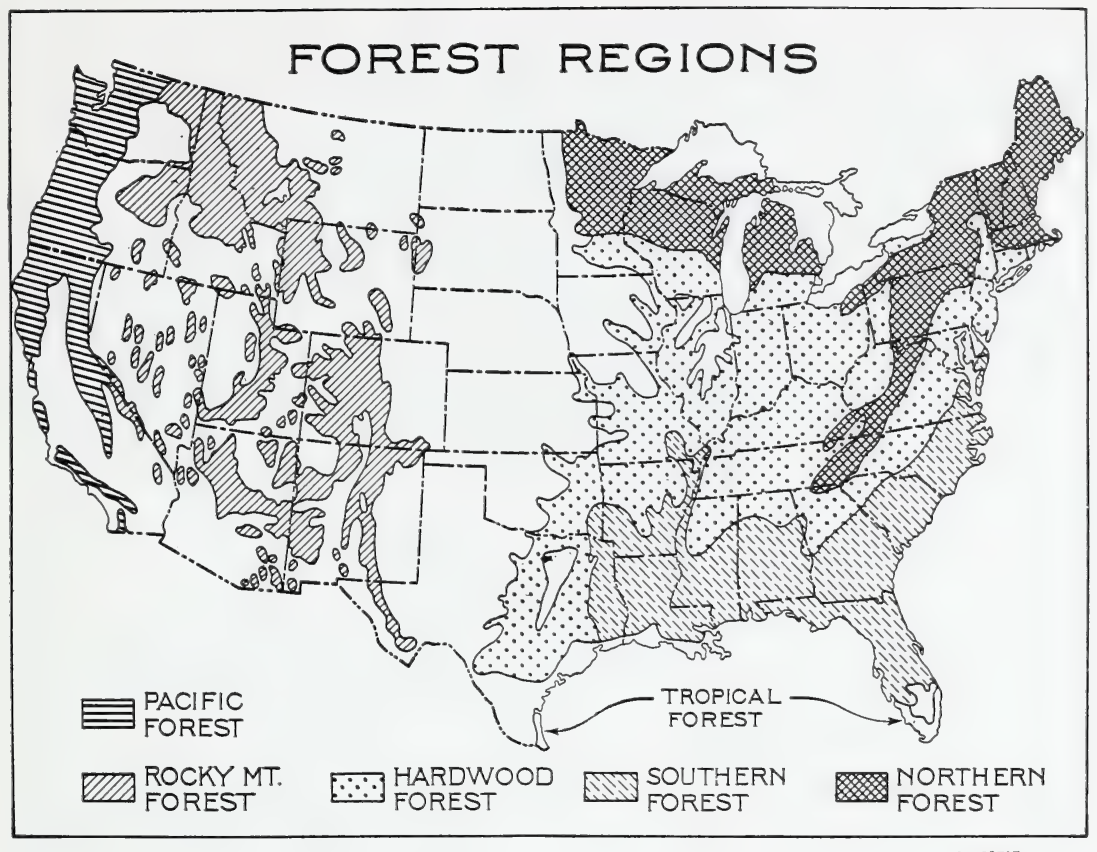

FiguRE 6.-What tree species characterize the six principal forest regions into which Nature has divided the United States?

and 89 percent of the temperate hardwood forests are in the North Temperate Zone.

Distribution of forests in the United States. - Nearly one-third of the continental land area of the United States is forested land of one sort or another; in the days of the vioneers, it was nearly one-half. Nature has divided our country into six principal forest regions (fig. 6).

The northern forest region was the first land to be logged, so it now contains comparatively little old growth. White pine was the first important forest contributor to the settler's needs in this region. It supplied this country with timber, and furnished Great Britain with masts and spars during the Colonial period. Spruce, the king of pulpwoods, and fir now occupy more than one-third of the total forest area of this region.

The hardwood region covers a large part of the central area of the eastern half of the United States. Its species include the maples, oaks, and hickories, in variety and abundance. On the better soils grow yellow poplars, or tuliptrees, and black walnut.

The southern forest region has the largest acreage still producing timber and gives promise of extensive production of pulpwood. Its yellow pine is the only remaining important source of large-timber production in the eastern half of the United States. Longleaf and slash pines are the principal southern pulpwood species. Cypress, tupelo, sweetgum, ash, and other commercially important hardwoods grow naturally in the river bottoms of this region and represent one of the most important sources of our present hardwood supply. 
The forests of the Rocky Mountain region are made up of relatively small timbered tracts mostly of ponderosa and lodgepole pine. The forested ridges and higher mountain plateaus are interspersed with great treeless stretches, sometimes arid, sometimes rocky.

The Pacific coast region is the native home of the large Douglas fir, pines, hemlocks, cedars, and redwoods. This region, with about one-seventh of the total commercial forest area of the United States, contains more than half our total saw timber. The coastal belt of Oregon and Washington, eastward to the timber line of the Cascade Range, has dense stands of large timber, mostly Douglas fir. Alaska has great reserves of virgin timber in her coast forests.

The tropical forest region in the United States is limited to very small areas in southern Florida and Texas where the tropical species probably sprang from seeds washed ashore or carried by birds from Central America, South America, and the West Indies.

\section{How Do Forests Help in Our Daily Activities?}

In the bome.-Wood is always used to some extent in the building and furnishing of a home. The all-wood house is not as common as it once was, but it is estimated that 8 out of every 10 houses in the United States are still built principally of wood. Other modern houses are often brick veneer over a wood structure.

Even though metal has been used by some companies as a substitute for wood in furniture, 95 percent of all household furniture is still made of wood. As the population of the country has increased, so has the demand from furniture companies for lumber increased.

Furniture and countless other things are either painted or varnished, and the forest supplies three important ingredients of finishing liquids: namely, turpentine and rosin from the pines of the South, and oil from the seeds of the tung tree, a native of China which has been introduced successfully into the United States.

A home without trees is like a picture without a frame. Trees beautify the exterior of our homes and protect them from wind and sun and storm. Many of the magazines, newspapers, and books which we enjoy in our leisure are available to us because we have learned to make paper from wood. It is possible that the draperies at the windows of our homes were once just as much a part of a great forest as was the log on the hearth. (See tables 3 and 4 , pp. 42 and 43. )

Forests and food.-We seldom think of the forests as a source of food, but our favorite dishes and festive holidays are enriched by the fruit of the nut trees. Those used in greatest quantity are pecans, chestnuts, walnuts, Brazil nuts, and cocoanuts. Most of these are harvested from natural forests.

Pecans rank high in nut production in our country. Chestnuts, once obtained in great quantity from extensive chestnut forests, are now imported from Italy. Black walnuts and butternuts come from the central hardwood belt. Persian (English) walnuts are produced in large quantities in the Pacific coast States. Brazil nuts come almost entirely from the virgin forests of the lower Amazon Basin in South America.

Maple sirup and sugar, produced largely in the woodlands of the Northeastern States, rank high both as delicacies and as energy foods. 
Livestock pastured in privately owned and national forests makes a significant contribution to our food supply. Moreover, wild game from the forest is a source of some of our food.

Besides supplying certain foods, the forest is largely the source of materials for the containers in which our foods are packaged and marketed. Cardboard packages, heavy brown cartons, wooden crates, and baskets bring our food to us in excellent condition. About half the cellophane, a popular material for food packages, is made from wood.

In Florida alone there are nearly 40 food-container manufacturers. Boxes, crates, lugs, hampers, and baskets are made of yellow pine, tupelo, sweetgum, evergreen magnolia, sweet bay, and several other woods. These industries use about 145 million board feet of wood a year for fruit and vegetable containers, lumber sufficient to build more than 7,000 six-room houses.

Forests, fuel, and clothing.-Fuel for heating houses and cooking food is another contribution of the forest to man's welfare and comfort. Although oil, gas, and electricity are replacing wood as fuel, firewood is still much used, particularly in rural communities. More than one-fourth of the total wood consumed annually in the United States is used for fuel. The total world consumption of wood fuel is equal to 250 to 300 million tons of coal.

Wood has long been used for shoes and in some countries is still commonly used for this purpose. In this country wooden shoes are used by workmen in some industries and the wooden heel is common, particularly on women's shoes. Much of the leather for footwear is tanned with extracts from forest trees.

Rayon made from wood fiber has proved itself as a garment fabric.

The forest also produces furs. Several of our most important fur bearers; namely, the muskrat, martin, fisher, and beaver, live in or along forest streams. Others, such as the fox, mink, and raccoon, frequent forest areas.

Forests and water for domestic use.-Millions of people depend on the forested watersheds for their water supply but not all of them realize it (fig. 7, A). A forested mountain slope acts like a sponge in holding rain water or melting snow and releasing it gradually, thereby regulating stream flow supplying pure and abundant water for domestic use. Big cities consume billions of gallons of water daily. The New York City watersupply system provides a dependable yield of 1,050 million gallons of water a day, more than half of which is brought by a gigantic chain of aqueducts and reservoirs from the forested Catskill Mountains 100 miles to the north, the rest coming from the Croton watershed.

Forests, illumination, and communication.-The forest supplied the pine knot, the torch, and the log fire which lighted the homes of our forefathers or provided them with means of communication in times of danger or distress. Today our homes, streets, and public and industrial buildings are flooded with electric light and threaded with lines of communication. An increasing proportion of the electricity for these services is developed from water power which in turn is dependent to a large degree on water from lands protected by forests (fig $7, B$ ). Were it not for such protection the smaller power reservoirs would fill with silt, much of the water would run off in floods, and the dams would be inadequate to hold enough water over periods of drought. 

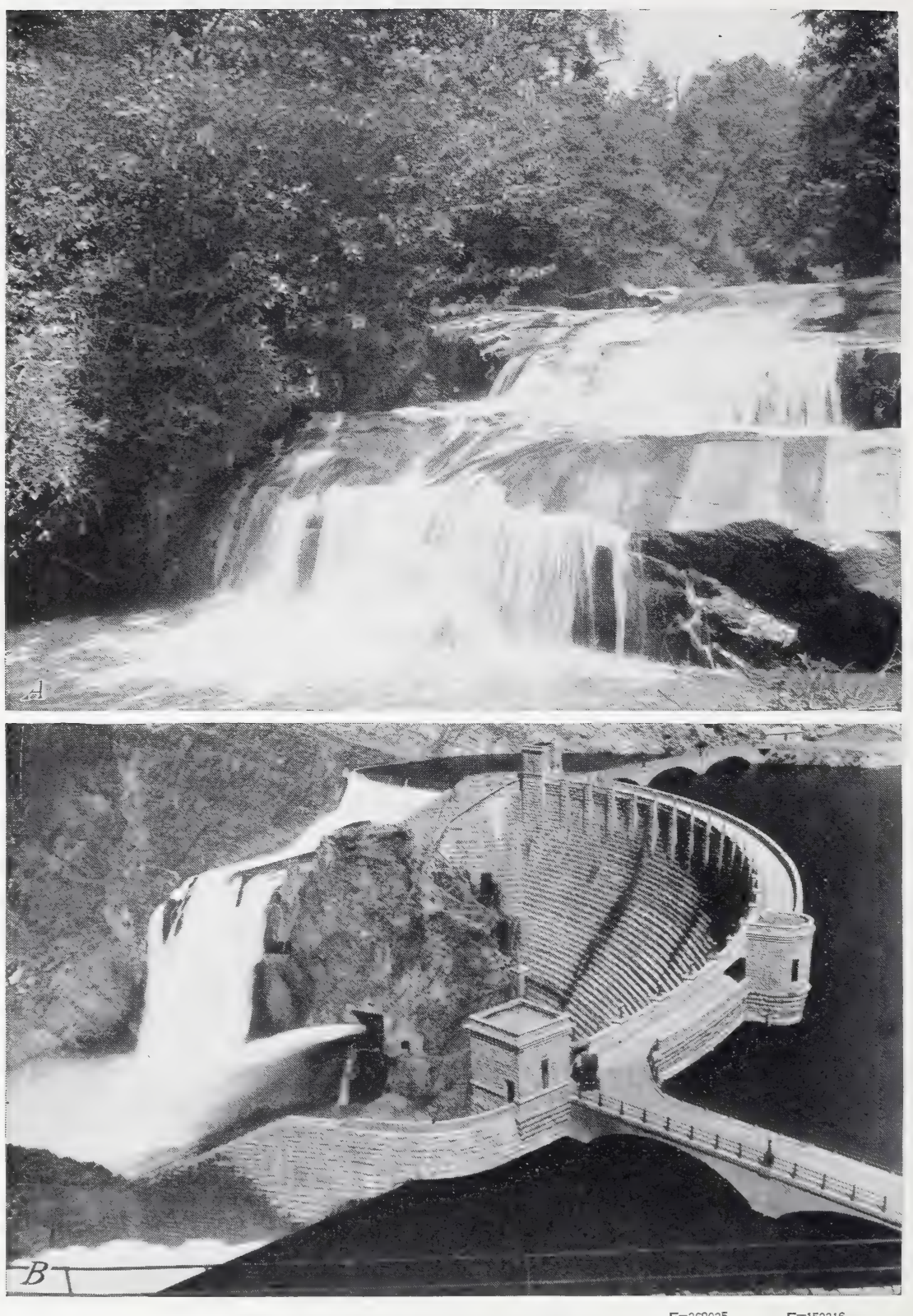

Figure 7,-How do forests affect water supplies $(A)$ for domestic use, $(B)$ for light and power? 
In many large cities electricity for lighting purposes and communication is delivered to the consumer by means of underground wires. In small cities and rural communities, however, these wires are supported by wooden poles. The total volume of timber in such poles used in this country yearly is about $37 \frac{1}{2}$ million cubic feet. The $3 \frac{1}{2}$ million poles would be enough to extend a telephone line around the world, with an extra line across the United States.

Forests and land transportation.-Forests have always played an important part in transportation. In the early days the covered wagon and the sailing boat, both made mostly of wood, were the chief methods of transportation. Then came the railroads with their wooden cross ties and cars. Steel has replaced wood for many railroad purposes, but the wooden tie is still in demand because no substitute has been found which so successfully absorbs vibration. Each year the railroads use about 55 million wooden ties to keep up their tracks. They have paid around $\$ 120,000,000$ a year for these and other timbers. The increased use of treated ties has caused some decrease in the number needed. It is also significant that onetwelfth of all freight revenue is obtained through the shipping of forest products. (figs. 8 and 9).

Recent electrification of railroads indicates a still greater dependence on forests. Power for such purposes must be cheap and dependable. One of the transcontinental railroads has more than 600 miles of electrified lines which are directly dependent upon forest streams for their power.

Forest highways built primarily to aid in fire suppression have become a part of the national network of roads open to the public. The forest contributes large quantities of freight for the trucks on the highways. These facts indicate an important relation between forests and transportation.

Forests and water transportation.-So important is water transportation in the distribution of goods in many parts of the United States that the improvement and maintenance of navigable channels and harbors has been made a Federal responsibility. Forest growth protecting the headwaters against too rapid run-off of rain and snow with consequent washing of soil is needed to help regulate stream flow. Where there is no such protection, clogging of stream beds and irregularity of flow often hinder navigation.

Wood has given way to other materials in the change from raft, birchbark canoe, and wooden windjammer to modern shipping vessels, but there is still a strong demand for wood for docks, decks, piles, and ship finishings and furnishings. Lumber is an important part of cargoes from the Pacific Northwest through the Panama Canal to east coast cites. The cost of transporting logs from forest to sawmill has been low, because wood floats. This fact has had much to do with the location of sawmills and important cities on streams and shore lines.

\section{Will Industry Become More Dependent Upon Forests?}

Lumbering and its influences.- The United States is the greatest lumberproducing and wood-using country in the world. (See tables 3, 5, and 6, pp. 42, and 44.) Lumbering was our pioneer industry. Forest products helped in the building of our Nation. Forests and wood-using industries still furnish employment, support communities, and represent investment 


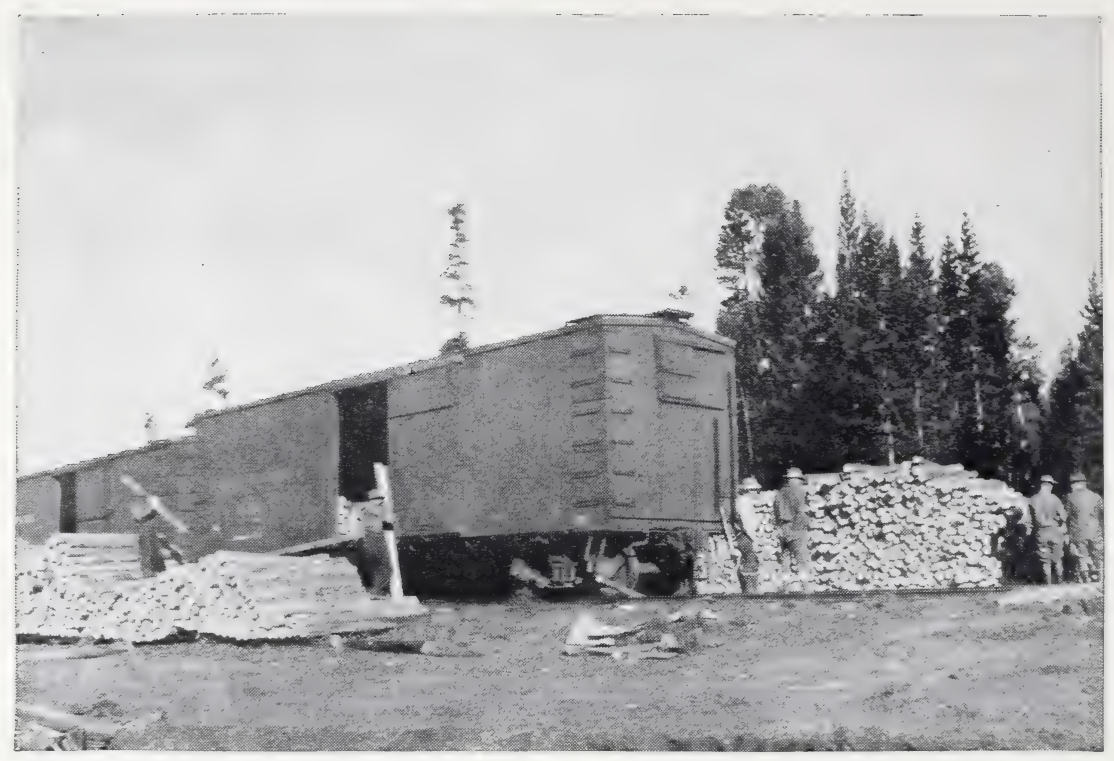

$\mathrm{F}-222318$

FIGURE 8.-What part does the forest play in keeping freight cars rolling?

FigURE 9.-What do naval stores still have to do with water transportation?

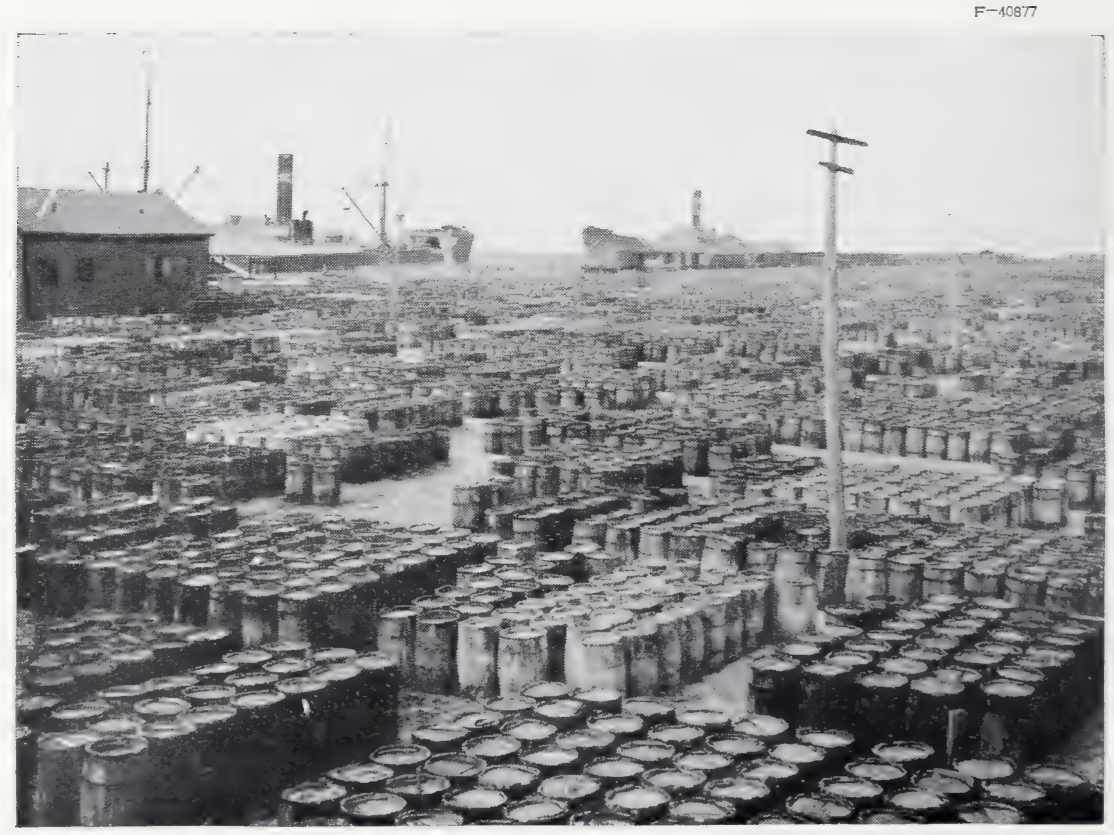


in standing timber, logging equipment, railroads, sawmills, woodworking enterprises, and lumber stocks. The value of our forests and primary forest industries has been estimated at something over 10 billion dollars (fig. 10).

Lumber production in the United States reached its peak in 1907 when 46 billion board feet were produced. Then came a gradual change in the type of construction throughout the country. Wood substitutes came into use. Opportunity for opening new lands, which formerly had meant a big building program, decreased. General business depression that began some two decades later greatly reduced lumber consumption. Production of lumber dropped to 10 billion board feet by 1932; however, business recovery brought about a new building program and lumber production has more than doubled that figure.

Forests determine the location of many industries.-If the forest is used up without thought of the future, the flourishing mill town soon disappears. The center of lumber production changes as forests are cut away, and industries are often forced to obtain their lumber supply from distant forests. Furniture manufacturing, for example, was centered mainly in Michigan, in proximity to the forests; but now two-thirds of the wood for this industry must be shipped in. If the forest is logged in such a way that the young trees are protected and given a chance to provide a continuous supply of timber, then towns and their wood-using industries become permanently established.

Almost every American industry depends upon the forest for lumber. Even when manufactured goods do not contain wood, they are usually shipped in wooden or wood-fiber containers.

We do not usually think of wood in connection with mining, yet more than $\$ 45,000,000$ a year is paid for timber used as supports in mines.

Different woods for different industries. - Since each species of tree produces wood with characteristics very similar to and differing widely from woods produced by other species, and since the wood of one species may differ in the same log, a wood user has a wide selection. The builder generally uses pine, fir, spruce, hemlock, redwood, cedar, or cypress. The factory turning out boxes and crates uses pine or hemlock, tupelo, and many other kinds of wood. The maker of handles for striking tools, such as the hammer and ax, needs hickory. The maker of handles for shovels, hoes, rakes, and forks uses ash. Handle stocks must be hard, strong, tough, and stiff. The furniture factory needs oak, walnut, maple, birch, sweetgum, and many other kinds of wood, depending upon the kind of furniture being made.

Telephone and telegraph poles of southern pine, western red cedar, and northern white cedar are most common. Southern pine poles are treated their entire length to increase their durability. The cedars are only butt treated since they are naturally very durable.

Dogwood and persimmon are standard materials for shuttles used in weaving cloth because these woods stay smooth under rubbing. Sweetgum, yellow poplar, walnut, oak, and other woods make good veneers. Oak has always been the principal cross-tie wood. Chestnut, once used extensively for cross ties, is on the verge of extinction because of the chestnut blight. Many woods have many uses, but each has its best uses.

Forests and power for industry. - Aside from producing raw materials for industry, the forest affects industry through its influence upon stream flow, and thereby on industrial water power. Power developed from streams has long been the motivating force of the great manufacturing industries 
of New England and New York, and of late years has made possible the industrial rise of the Carolinas. In the early years of this century, with the deforestation of much of New England, the dwindling of streams aroused much anxiety over the threat of insufficient water power for their industries. This concern grew until the Federal and State Governments were induced to acquire forest land in mountain areas so that protective forests might preserve stream flow.

Naval stores. - In the longleaf-slash pine region stretching for a thousand miles along the Atlantic and Gulf coasts from North Carolina to Texas the so-called naval stores industry, started in early colonial days, still operates. Such materials as rosin, turpentine, and resin oils are produced either from the gum of living longleaf and slash pines or from the resin-soaked heart-

FIGURE 10.-How does the forest help keep the wheels of industry turning?

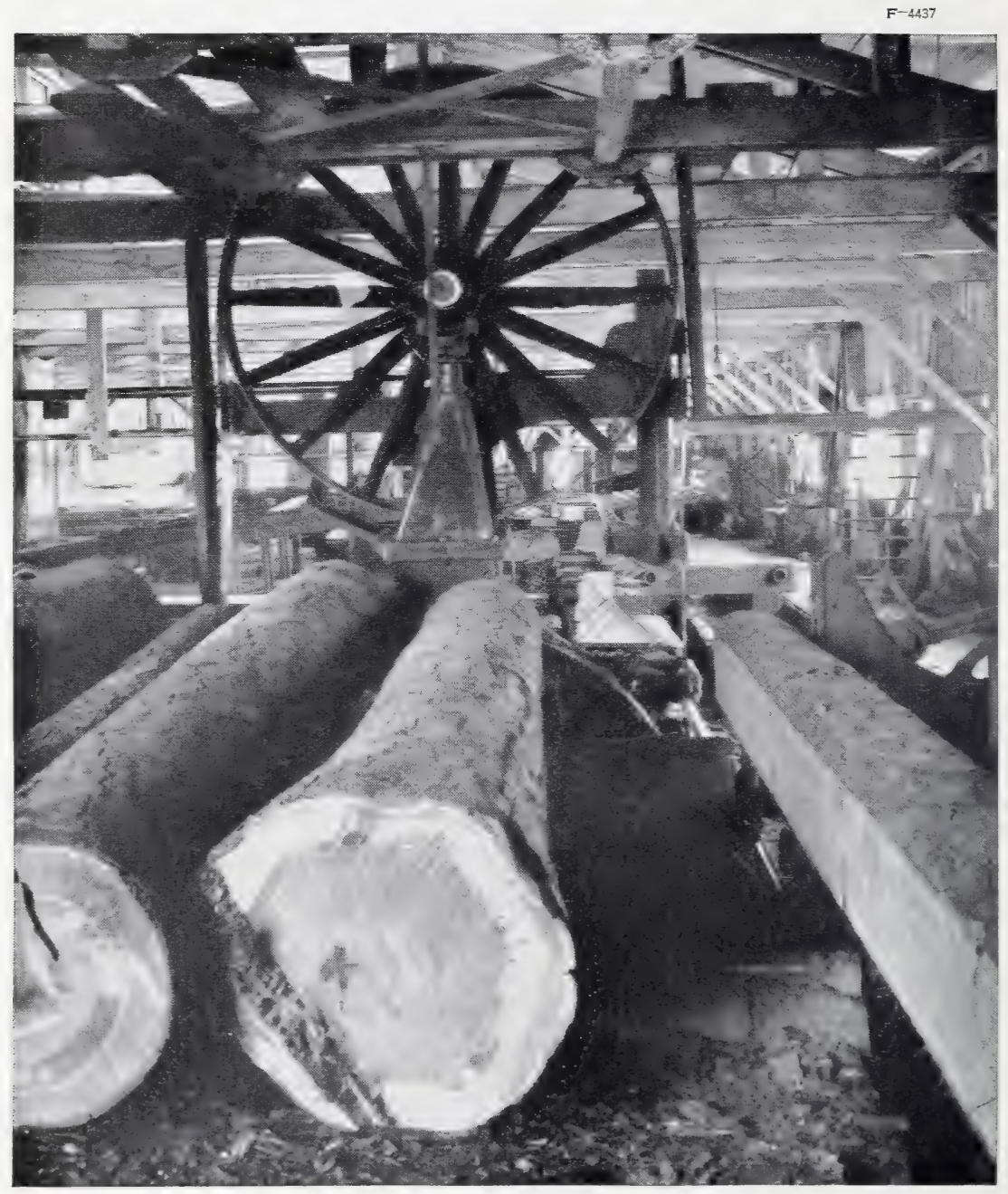


wood of the dead trees and stumps of these two southern species. In camps deep in the piney woods, many thousand laborers extract the fragrant gum which is distilled to produce turpentine and rosin for world commerce.

The term "naval stores" goes back to the days when tar and pitch were essential to the building and upkeep of wooden ships. The wooden ships have been replaced by vessels of steel, with small need for tar or pitch, but the old name "naval stores" still clings to these products. They are used in the manufacture of paper, soap, varnish, printer's ink, paints, linoleum, and other manufactured materials in daily use.

Pulp and paper industry.-As the demand for lumber and certain other forest products has declined, the amount of wood needed for other purposes has increased. The most notable increase is in wood needed for making paper. Eighty-five percent of our paper is made from wood. Nearly 5 million tons of wood pulp were produced in 1937. The industry is distributed in 37 States, and is located in forest regions not only to be near the source of wood, but also because cheap power and an abundance of clear water, requirements of paper making, are usually available.

Changes in wood use.-At one time charcoal, wood alcohol, and acetic acid manufacturing from wood was considerably more important than today. The production, from wood or bark, of tannin for tanning leather and making inks and various dyestuffs has been reduced by substitutes, but forest tanning materials still are valued at about 10 million dollars annually. Practically all tanning of sole leather is done with vegetable tannin from wood, bark, and leaves.

Manufacture of rayon and cellophane constitute two of the newer uses of wood. Wood and cotton are used about equally as the raw materials from which these products are made. Comparative prices usually determine which is used.

Plastics, which are made by combining certain chemcials with sawdust or wood flour, are gaining in use daily. Fountain pens, telephone parts, radio and automobile trimmings, combs, and thousands of other articles are being made of plastics. The plentiful supply and cheapness of wood give it advantages over competing materials for plastics.

Substitution not necessary. - Some believe we should use wood substitutes and save the forests by decreasing the use of forest products. Such substitution is not necessary. Conservation is wise use. The greater the demand for wood, the greater the number of trees planted and the fewer wasted. Substitution tends to save the trees, to destroy the wood-using industries, and to decrease employment of people dependent on the forest. If our forest lands are properly managed, they are capable of producing an adequate supply of wood. Forest products need outlets, and forests need management, not hoarding.

\section{What Part Do Forests Play in Commerce?}

Domestic trade.-Locally, forest industries afford markets for farm crops. Logging camps and mill towns require vegetables, fruits, meats, and dairy and poultry products. Hay and grain are required where horses and mules are used in logging. Farmers within trucking distance of a pulp mill or woodenware factory may usually sell timber to advantage. Some factories depend solely on such sources of supply. Forest industries also create a market for equipment and other manufactured goods. 
Maple sugar, forest fruits and nuts, Christmas trees, and decorative materials, though minor forest products, are of great economic importance in certain areas where they are produced.

In supplying raw materials for industries, forest products furnish a basis for trade and exchange. Financing of forest-land holding, logging operations, sawmills, pulp mills, and other wood-processing plants involves tremendous capital. In addition, the trade and exchange in forest products between localities and nations is the basis of considerable commerce.

Since 1926 the West has produced most of the lumber in the United States. The South is second in production. The long haul necessary to get lumber to the Central and Eastern States accounts for a large part of the freight tonnage of the railroads, although it substantially increases the cost of lumber.

Exports and imports. - The United States imports large quantities of pulpwood, but exports lumber to those countries lacking in forests and to those countries that do not produce certain kinds of wood for which they have need. The United States ranks fifth as an exporter of lumber-the Union of Soviet Socialist Republics, Finland, Sweden, and Canada being ahead of us in 1935. Tropical countries may have an abundance of hardwood but have to import softwoods for construction purposes. These tropical countries in turn supply the United States with certain hardwoods, such as mahogany, that do not grow in our temperate climate. At the same time we export other hardwoods, such as oak, walnut, gum, ash, and hickory. It is necessary, then, not only to maintain our forest resources for domestic needs but also to maintain our foreign trade in forest products. (See table 2, p. 42).

About 80 percent of the total trade in forest products is softwoods (conifers), principally for construction and paper pulp. Temperate hardwoods used for staves, railroad ties, furniture, finish, cabinet work, and other special purposes, make up about 18 percent, and the other 2 percent is made up of tropical hardwoods, which are exported almost entirely as furniture, cabinet, dye, and tanning woods.

Most of the trade and exchange in forest products is between Europe and North America. The great exporting countries of Europe are Sweden, the Soviet Union, and Finland. Imports greatly exceed exports in The British Isles, Germany, Italy, France, Belgium, and Denmark. Japan is the leader in Asia in exports of forest products, whereas China has been stripped so bare of forest growth that she must import timber, especially of the higher grades and larger sizes. (See The Supply in Foreign Countries, pp. 31 and 32.)

\section{How Do Forests Help Provide Gainful Employment?}

In the woods.-Forestry and the lumber industry alone employ an average of 650,000 regular workers in the United States. The woodlands also provide a large amount of part-time work to 2,500,000 farmers who cut wood and timber from their own lands and work it up for their own use or haul it to market.

In forest industries. - Another 650,000 persons are employed in woodworking plants of various sorts and in the pulp and paper industry. Persons employed in transporting and merchandising lumber and other forest products are not included in these figures. The 1935 United States census shows 20 industries directly dependent on the forest for raw materials. 
Among the 16 major manufacturing industries, this group ranks fourth on the basis of number of wage earners employed. Persons employed in the 20 branches of forest-products manufacturing total nearly a million. In addition, the making of paper goods, pulp, rayon and allied products, wood distillation, and charcoal manufacturing employ more than 200,000 persons.

In foreign countries. - In European countries, where many forests have been for a long time under sustained-yield management-growing as much or more than is cut - there is even a greater proportionate employment in forestry and forest industries. In Denmark 750,000 acres of forests furnish employment equivalent to full-time work for about 6,000 persons and considerably more part-time work for those who spend most of their remaining time at work on farms. In Sweden the forests furnish employment for some 90,000 workers.

The figures for England are interesting, because they show the increase in amount of employment as forests develop from the planting stage to full growth. The British Forestry Commission estimates that, on the average, forests in the planting stage require one full-time worker for 100 acres but in the older productive state one worker is required to 50 acres.

An unending supply of labor.- The forest offers a great reservoir of work. This has been demonstrated by the Civilian Conservation Corps and emergency relief employment agencies of the United States. In the first 6 years of operations by the C. C. C. about 2 million boys and men were employed on forestry and park projects. Previous to 1936, forest work as a means of occupation for the unemployed had been used in several States, notably California, Connecticut, New Hampshire, Massachusetts, Wisconsin, and New York.

\section{Why Are Farm Forests Likely to Increase in Importance?}

Farm woodlands, a forest resource. - The remote and vast forests often attract so much attention that the little forests known as farm woodlands are completely overlooked. These small forests are on $4 \frac{1}{2}$ million farms scattered in every part of the country where trees will grow. Together they contain 185 million acres or an area equal to one-half the cultivated land and onethird the total forest land. The fact that the farm forest needs no annual planting and cultivation and that the timber may be harvested in the winter makes it fit well into the general farm program. Then, too, a forest crop may be grown on land too poor for other crops. With the depletion of virgin timber in many areas, the nearby wood-using industries are turning to the farmers for raw materials.

The farmer, a producer of forest products.-Most of the farm woodlands are in the eastern part of the United States relatively near the great wood-using and wood-importing regions. A nearby market is a distinct advantage in farm timber production. The fact that the price of logs has remained relatively higher than other farm products in comparison to pre-war levels also points to possibilities in farm timber production.

Farmers sell about 190 million dollars worth of timber and related products per year. One-third of the timber of all kinds comes from farm woodlands. The best quality logs bring the highest prices for veneer. The next best bring most when sold as sawlogs to be cut into lumber. Sawlogs and veneer logs now cut on farms amount to more than a billion board feet annually. The next grade of logs is most valuable as pulpwood to be 


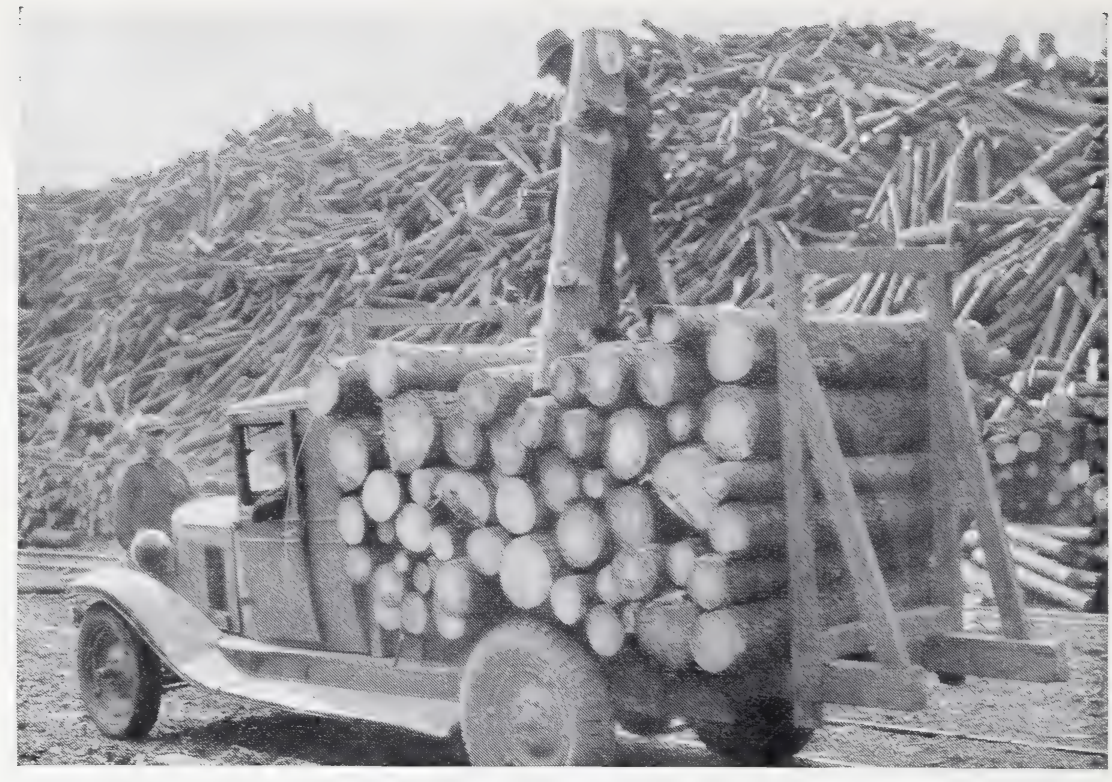

$\mathrm{F}-244088$

FIGURE 11.-What will be made of this farmer's crop? What suggests it will not be lumber?

made into paper (fig. 11). Finally, the material left after the better grades are marketed may be sold for fuel. The use of wood for fuel is second in extent only to the use of wood for construction. During depression years thousands of farmers sold a cash crop of fuel wood from their woodlands for the first time.

In addition to the cash income from sale of wood the southeastern farmer has the income from turpentining his trees until they are salable for more profitable purposes. The New England farmer has the maple sugar crop to sell while his trees are growing. Sales of railroad ties, fence posts, poles, and select kinds of wood for making tool handles and water-tight barrels may add to the farmer's income.

Agricultural economists class forest products with leading farm crops of the country, since they rank ninth in actual value.

The farmer, a manufacturer of forest products. - The farmer may find profitable employment for himself, his teams, and equipment in the forest during the winter or other seasons when farm work is slack. In some cases he may work for wages in nearby logging camps or mills but more often he works in his own woods, getting out timber for home use or for sale.

A farmer may sell his entire wood crop on the stump. In this case others do the work of cutting and working it into the product for market. The farmer who selects and cuts his own trees, grades his own logs, and saws them into lumber obtains the greatest cash income from his woodland because it provides a way to sell his labor, too. The modern trend toward power farming and development of portable sawmills may increase the amount of iumber and other wood products manufactured on farms. Hewea ties, fence posts, poles, shooks, and bolts for making barrel staves or handles may be prepared for sale by the farmer. 
In some areas farmers have cooperative sawmills, or a farmer who has a sawmill saws his neighbor's logs on shares or for cash or other pay. Similarly farmers may process their other forest products to increase their cash income.

The farmer, a user of wood.-Its many and important uses make wood indispensable on every farm. Wooden buildings and fence posts, poles, and equipment create a constant demand for lumber on the farm. The farmer who can supply his own needs reduces his cash outlay and can keep his farm in much better condition. Farmers use the greater share of the fuel wood they produce. Wooden boxes, barrels, and crates are used in enormous quantities in marketing farm products.

Grazing farm woodlands. - The value of forage found in farm woodlands varies greatly with the forest type.

In the Eastern, Lake, and Central States, the grazing of cattle, sheep, and goats in hardwood stands is incompatible with the production of forest crops. Since the most valuable hardwood trees frequently have the most palatable foliage, grazing degrades the forest by preventing the reproduction of the more valuable species. Where hardwood woodlands are grazed constantly and forage becomes scarce, practically all reproduction is eliminated, the soil becomes packed, forest conditions are destroyed, and grass takes possession of the site. The farmer's problem is to decide from the standpoint of best land use whether to maintain all his woodland for the production of forest crops by fencing and eliminating grazing or to convert a portion of his woodland to other farm uses. Grazing in coniferous forests in the Lake States and in the Northeast makes no great contribution to the farm economy.

In some coniferous forests, dual use of the woodland by cattle and sheep is entirely feasible, provided grazing is properly regulated. For example, the open ponderosa pine forests of the West provide palatable forage which, through proper use, can be utilized without destroving the productiveness of the forest (fig. 12). Ponderosa pine has low palatability and is seldom eaten by stock provided numbers of livestock are adjusted to available forage. Grazing in other coniferous forests in the West, where the forest is often broken by natural meadows and openings, is of great importance to farmers, but the forest proper contains little forage and damage from grazing is negligible.

In the pine forests of the South, the grasses are low in palatability but considerable stock is grazed. Cattle range through the woods with little regard to ownership lines and, with moderate regulation, danger of serious damage to reproduction is slight. Where woodland pastures are fenced, damage to pine seedlings can be serious if too many head of cattle are grazed. Once the young growth becomes well established, however, the forage is so depleted by shade as to almost exclude grazing use. Sheep and goats will eat buds and new growth on pine seedlings and should be fenced out of pine plantations and stands having seedling reproduction. Longleaf pine forests should be protected from hogs, sheep, and goats at all times during which regeneration of the forest is taking place. Grazing in southern pine forests on the basis of native grasses is generally uneconomic and the real solution to the grazing problem is through the use of improved pastures and the growing of hay crops.

Protection given.- The protection given by woods to crops, buildings, and livestock against winds is of great value to the farmer. In the Prairie States, and more especially in the Great Plains States where natural tree 
growth is generally limited to stream banks, farm tree planting is done primarily for windbreaks. Holding snow to increase soil moisture, checking wind velocity to reduce drying and blowing of the soil, and greatly improving the appearance of the farmstead are protective and aesthetic values of the farm woodland.

The forests far removed from the farm serve agriculture in many areas by holding the soil in place on slopes and along the banks of streams. Where forested slopes have been logged, many thousands of acres of rich agricultural bottom land have been ruined by deposits of sand, gravel, and boulders, washed down from the bare slopes. In some States, particularly in the South, tree planting on gullied parts of farms to check erosion is one means of putting otherwise waste areas to profitable use.

Water supply.-Irrigation supplies the lifeblood of certain agricultural communities. More than 240,000 farms, about half the total number in the 11 Western States, are dependent upon irrigation for watering crops. A large part of the water used to irrigate these farm lands comes from neighboring forested mountains (fig. 13).

The investment in irrigation agriculture has been estimated at more than 6 billion dollars, and the value of the crops produced at 900 million dollars in 1929. Without the forest cover on the watershed, the flow of water would be irregular and uncertain, larger and more costly storage reservoirs would be necessary, and great losses in silting of reservoirs and ditches would follow.

\section{How Do Forests Serve in Study and Leisure?}

An outdoor school.-Nature has set up a school in the forest. The varied plants and animals, the scents, sights, and sounds open new books to those who wish to learn. The forest offers a range from the ABC's of nature study to the complexities of ecology. Every level of understanding from the pictured primer to scientific research may find satisfaction in the forest environment.

Recreation.-Forests play an increasingly important role in leisure activ-

FIGURE 12.-What are the three marketable products from this forest area?

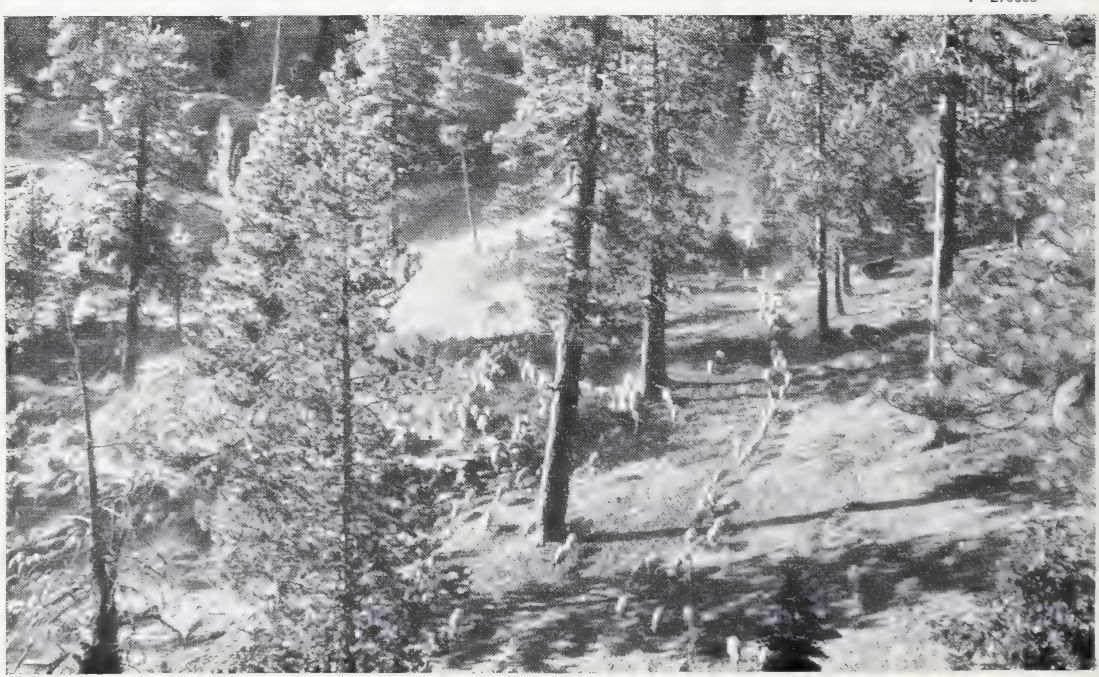




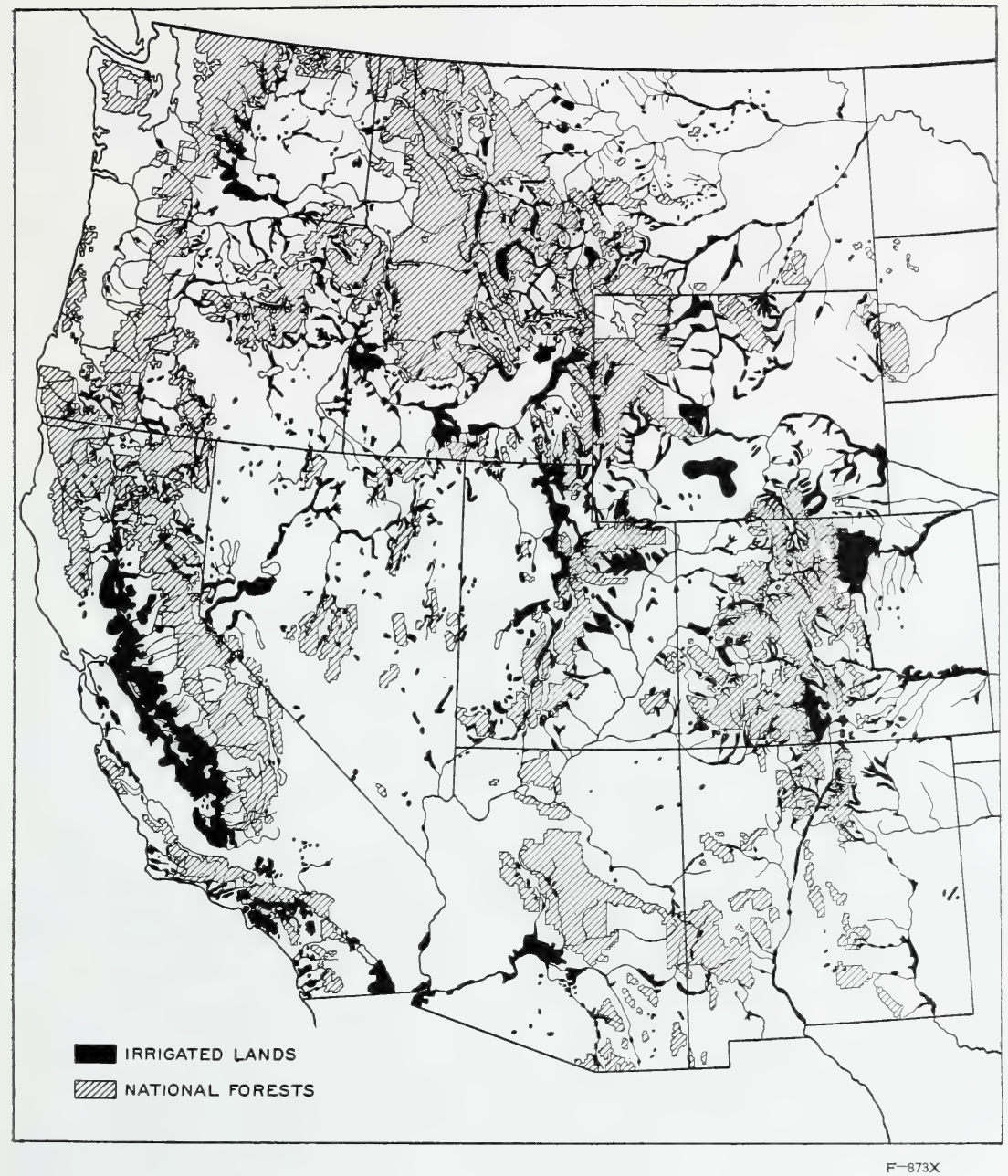

FIGURE 13.-Where do the majority of western streams supplying water for irrigation rise?

ities. Once a luxury, forest recreation has been made accessible to the millions by the automobile and good roads. The development of several thousand areas in the national forests in 36 States and 2 Territories for camping, fishing, hunting, swimming, and many other sports has greatly extended the use of forests for recreation. In addition to the 161 national forests, many national and local parks, and State and municipal forests provide similar facilities. The great increase of forest visitors in recent years is indicative of the importance of forests in this field of man's interests.

Wildlife.-The fact that forests provide the homes for a great many of our wild animals adds to their recreational value (fig. 14). The hunter with camera, field glass, or gun is lured to the forest by the wildlife. What is more interesting than to study the actions of the deer in its native haunts or the engineering feats of the beaver? 
Nature's great scheme of balance may be learned from observation of the wild animals of the forests. Man has just begun to study these relations. Nature undisturbed maintains an almost perfect balance between the number of wild animals and the available food. When man removes all such animals as the coyote, wolf, lynx, and wildcat, or such birds as the hawks and owls, nature's balance is upset. Such creatures normally prey on other animals for food and thereby keep them from overpopulating a given area. The weaker, slower, and less alert animals are first captured, leaving the stronger, more agile, and alert to carry on the race, and insuring a better stock than if the number of undesirables were not reduced.

The impact of civilization on natural conditions disturbs the original balance. Man uses the forests to maintain his institutions. Under modern conditions, therefore, there is no natural balance and in a general way

FigURe 14.-What habits make a forest home necessary for the beaver, $(A)$, and the bear $(B)$ ?
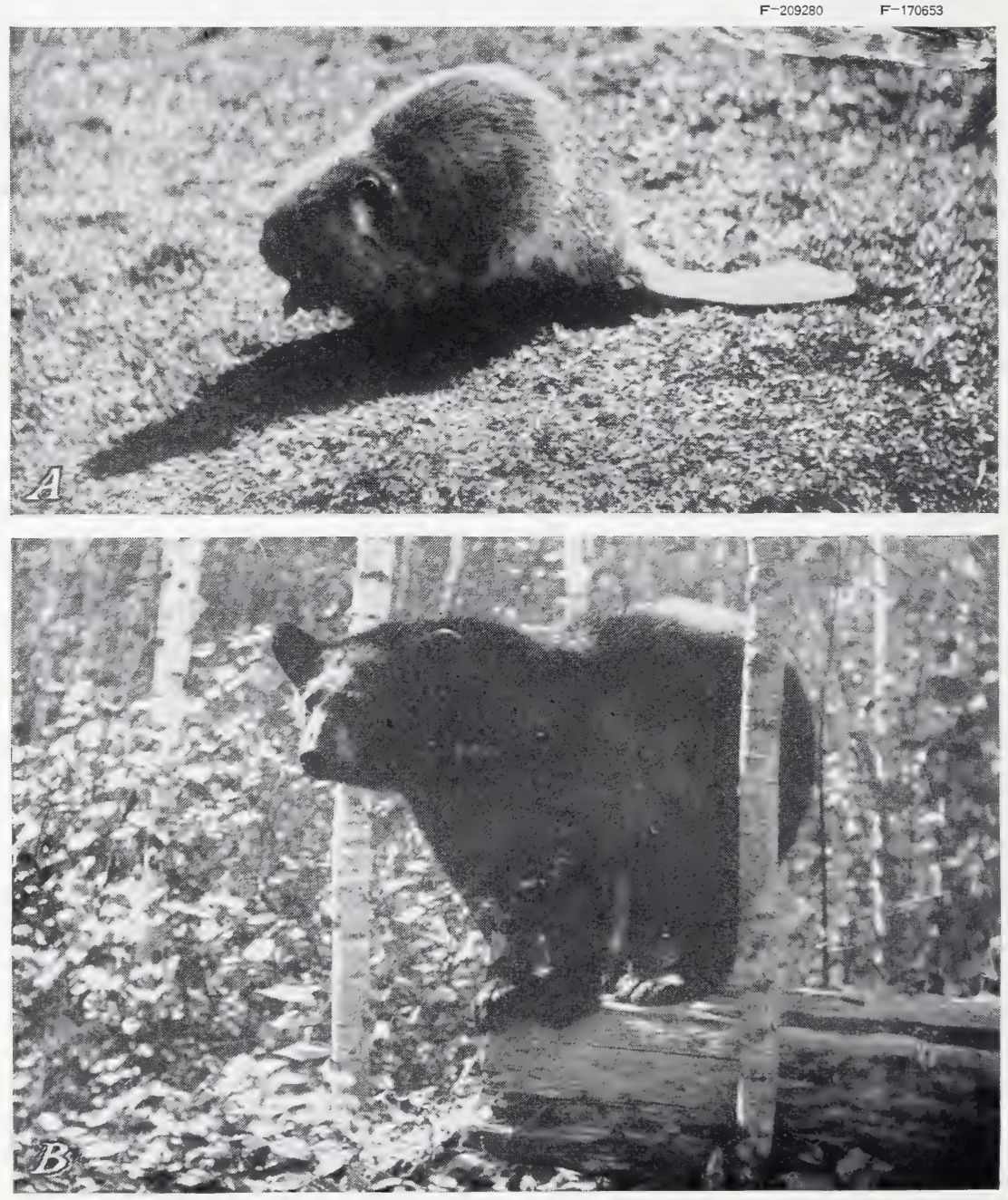
it is impossible to restore such a balance in forest properties. Practical considerations now and in the future will prevent the reinstallation of the balance of nature except perhaps on very limited areas.

Our civilization being what it is, it becomes necessary for man to create another type of balance through the manipulation of wildlife habitats and of wildlife itself. In this substitute balance wildlife management must be a very important part of forest management. The forests must be better protected and managed in the interests of fish and game by the control of forest fires, the encouragement of conditions that will contribute to wildlife food, shelter, and sanctuary, the production of shrubs and other species suitable for wildlife food, the management of timber stands with wildlife considerations in mind. In timber areas, for example, it may be desirable to leave sufficient cover for the wildlife, to leave a certain percentage of such so-called weed trees as persimmon, crab apple, mountain ash, and berry-producing bushes, for their value as a food source to the wildlife, or to overlook an occasional snag that may provide a home for a raccoon or a woodpecker. If a certain species of animal is scarce, it is necessary to protect it from trapping and hunting. If there are too many of any particular species for the amount of food that is available, it becomes advisable to reduce the number by increased hunting. It is considered wiser to take the lives of the surplus animals for human use than to leave them in the forest to die of starvation and disease.

Through careful management and restoration of forest cover a new set of conditions suitable to wildlife may thus be achieved. In this scheme of balance through management everyone, more or less, has a personal responsibility.

\section{Who Own and Manage the Forests?}

Forest ownership in the United States.-Communities, counties, cities, States, the Federal Government, individuals, and industrial corporations own forest lands. Some schools own forests as investments and as outdoor laboratories. Such forests may be classed either under public or private ownership. Forest ownership is the key to conservation because the owner determines how the forest is managed.

Private ownership.-There are approximately 630 million acres of forest land in the United States. About 462 million acres of this forest land is capable of producing valuable timber and other forest products. About three-fourths of this commercial forest land, including the best, is in private ownership.

Industrial ownership is the most important type of private ownership, because in these forests opportunities for supplies of raw materials and for employment are most abundant. In many cases, these forests have been logged with no thought of the future and the land has been entirely depleted of forest growth. The best forest land is owned by lumber, pulp and paper, land, and mining companies, by naval stores operators, railroads, and others. Industrial ownership is common in the East and public ownership in the West.

Farmer ownership of forest land is next in importance to industrial ownership. There are 185 million acres of forest land so owned. This means that about 30 percent of the total forest acreage is on farms. About 95 percent of this farm forest land is east of the Mississippi River. More than half of that is in the South. In the South, privately owned forests are about half in industrial and half in farm ownership. 


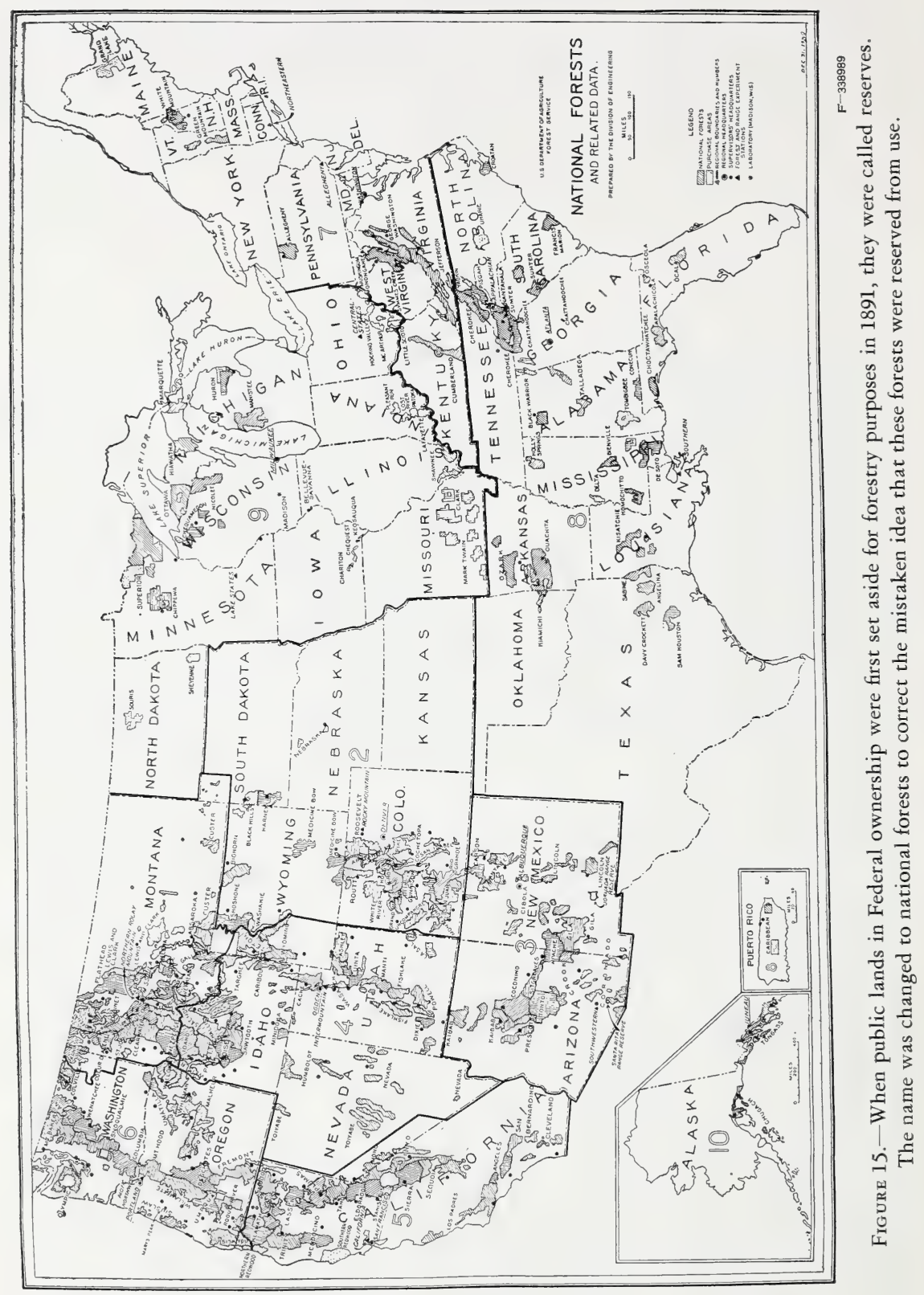


National forests. - About 176 million acres of forest land are managed by the Forest Service of the United States Department of Agriculture. This land is divided into 161 national forests (fig. 15). Some people who visit national-forest areas are disappointed to find them composed not entirely of stands of virgin timber. There are, of course, large areas of virgin stands in some of the forests, particularly in the Northwest, on which forest management suitable to such stands is being practiced. In the national forests there are also extensive range areas and lands above timber line that have never grown timber. Also there are old burns, and there are areas previously cut over in such a way that it is still possible to practice forestry on them through the medium of timber sales. In the West to some extent and in the East to a larger extent, national-forest acquisition of private lands by exchange and purchase has also added large areas of thrifty second-growth stands and a considerable acreage of land which has been destructively logged and otherwise abused and which must be planted before it can again start producing valuable timber crops. Since forests grow slowly it will be many years hefore these latter areas will again bear a stand of mature trees.

State and county forests.-Forty States own forest land and give it some management to make or keep it valuable. Land in State forests amounted to about $13 \frac{1}{2}$ million acres in 1939. It had been acquired as Federal grants, through tax delinquency, as gifts, and by purchase and exchange. The States are assisted in the protection of this land by the Federal Government, under the Clarke-McNary Act which provides forest-fire protection for both State and privately owned forest lands.

Many counties have acquired forest land through tax delinquency, but very few of them have attempted to develop or manage it. Certain populous counties, such as Los Angeles County, Calif., have acquired extensive forests primarily for watershed purposes.

Community forests.-A small beginning has been made in developing community forests in this country. Some New England towns have had forests for many years. In Europe this type of ownership is much more common. Sixty-six percent of Swiss forests and 20 percent of the forests in France and in Germany are community owned.

Commercial forest land.-About one-fourth of the total commercial forest area of 462 million acres, the poorest fourth, is in public ownership (figs. 16 and 17). Of this, about four-fifths, or 97 million acres, is owned and managed by the Federal Government in national forests, Indian reservations, and other areas. About 24 million acres are owned by the States, counties, cities, and communities. Commercial forest land in public ownership is protected and managed for permanent timber production and other uses. All forest land in Alaska is under public management.

Most of the federally owned land is in the West because public domain had not been entirely disposed of there before the Federal Government took steps to set it aside from private entry.

Noncommercial forest land.- The United States has about 11 million acres of forest lands in national parks and other areas which are not managed for timber production. There are also 157 million acres of lands in various parts of the country which, because of low productivity or extreme inaccessibility, are not listed as commercial timberlands. In this class might be included the open-grown piñion-juniper lands in the West, chaparralcovered areas in southern California, and the remote and inaccessible mountain ranges. These forests are of value, however, for watershed 


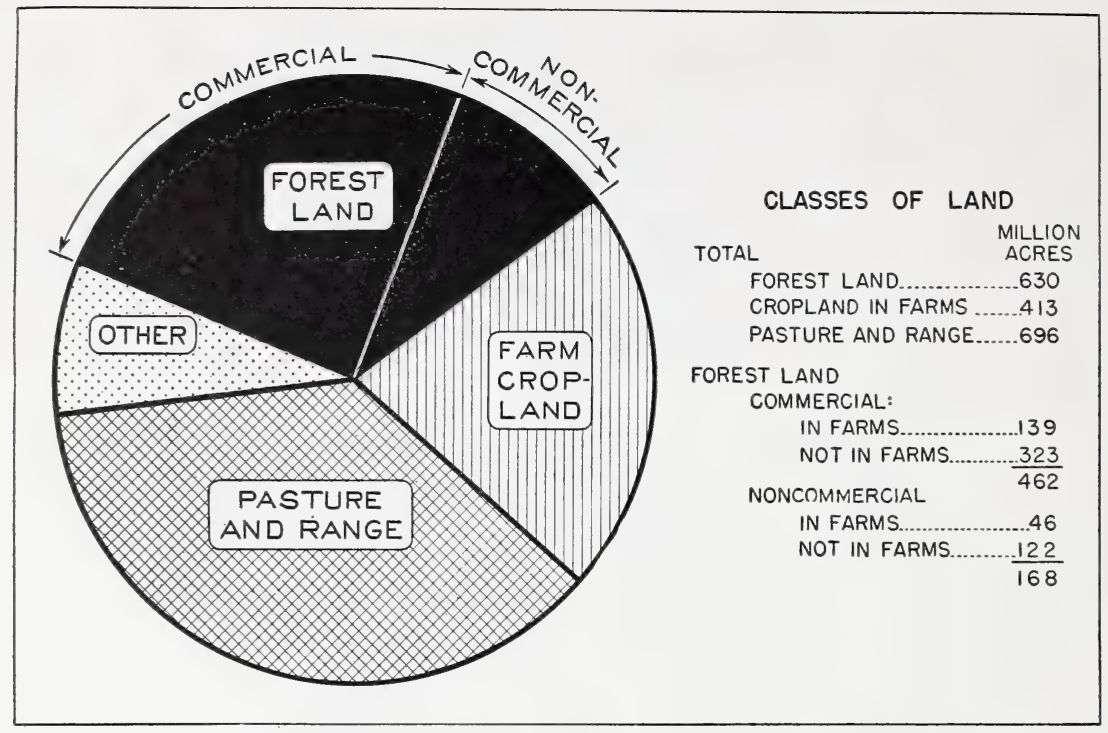

$830 \mathrm{x}$

FIGURE 16.-Will the area in forests increase or decrease?

protection and wildlife habitat. There are also many areas of low commercial productivity, the result of wasteful and careless lumbering followed by fire.

Distribution of foreign forests. - The Soviet Union has the most extensive forests of any country. The British Empire, including Canada, ranks a very close second. Each has more than one-fifth of the world's forests. Brazil and the United States come next. These four countries together have nearly two-thirds of the forest lands of the world (fig. 18). The remaining one-third is shared by about 50 countries. Great Britain, France, Belgium, and the Netherlands, which together have but 0.4 percent of the world's forests, control more than 30 percent in their colonies and dependencies.

Forest ownership in other countries. - The proportion of publicly owned forests to the total forest areas of European countries varies from 100 percent in The Soviet Union to about 20 percent in Great Britain and Ireland. In Finland, Sweden, France, and Italy the publicly owned forests roughly constitute about 30 percent of all the forest land. In Germany, forests are about half publicly and half privately owned. In Asia most of the forest land is in public ownership.

In Canada about 90 percent of the forest is in public ownership and is under supervision of foresters.

Most European countries have well-organized forestry departments. Russian forests are leased, with certain restrictions, to groups for management. Germany, Finland, and Sweden have public regulation of privately owned forest land. In France and Italy, the privately owned forests important for watershed protection are under public regulation. Canada, Great Britain, and Ireland have no public control over private timberlands. In Japan, there is strict public control over both public and private forests. In South America, Brazil is exceptional in providing public aid to owners 
for proper management of their forests. Several of the South American countries have established public management and supervision over their forests.

Consumption in foreign countries.-The difference in per capita use of timber in European nations indicates that where forests are extensive the people use much more timber than in those countries of small forest acreages (table 6, pp. 44 and 45). By intensive management many European countries have been able to offset to some extent a deficiency of forest acres by increased production in existing forests.

The supply in foreign countries.- Of the European exporting countries, Finland exports more than 300 million cubic feet of timber each year (about one-fourth of her total cut), and imports only about 1 million cubic feet of the better grades of hardwoods for furniture and shipbuilding. Pulp and paper, the making of which is one of her thriving industries, are among Finland's exports. She has abundant water power, vast quantities of small spruce timber suitable for making paper pulp, and cheap but very efficient labor. Finland is called the country of swamps, but might better be called the country of forests and lakes. Agricultural land forms only about onetwelfth of the entire land area, but nearly half of the total land area is actually productive forest land.

The European part of the Soviet Union has a forest land area about 10 times that of Finland, yet Finland's softwood lumber exports in 1930 amounted to more than three-fourths those of the Soviet Union. In the European part of the Soviet Union, wood is used in great quantities as fuel, not only for the heating of houses even in such large cities as Moscow and

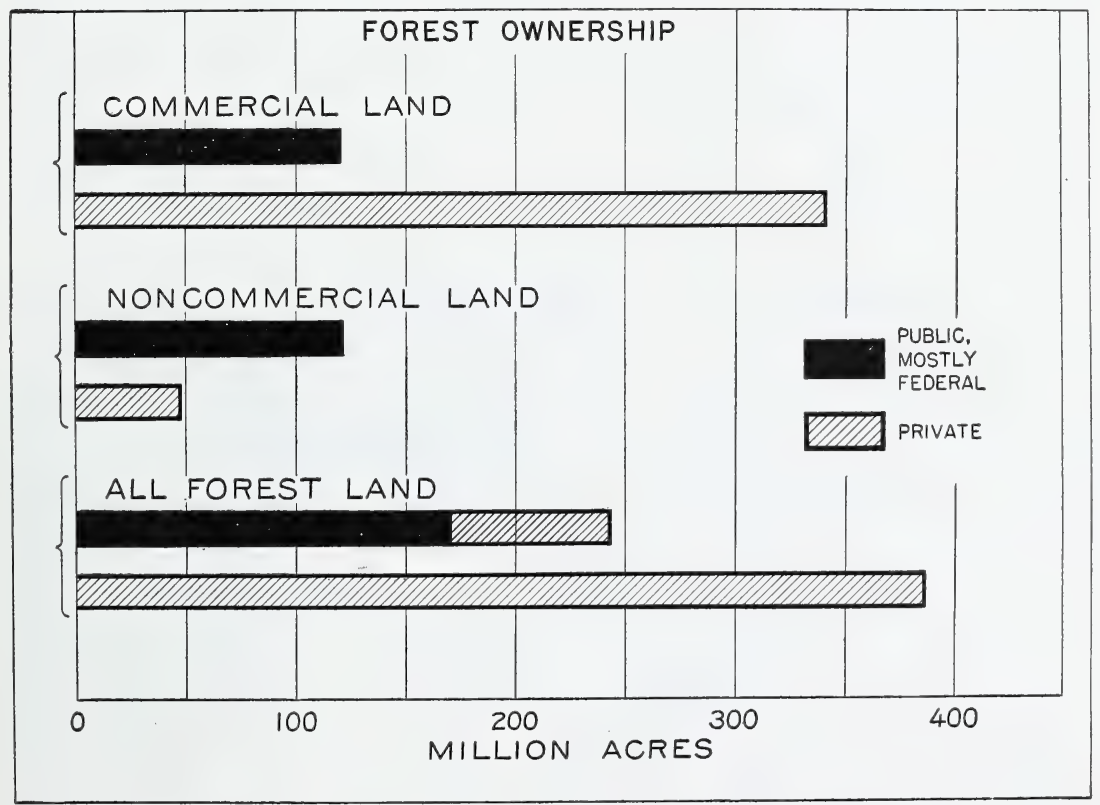

$832 \mathrm{X}$

Figure 17.- How does it happen that the Federal and State Governments own such a small part of the commercial forest land but such a large part of the noncommercial forest land? 
Leningrad, but also in industry and railroad transportation, and as raw material for numerous wood-using industries.

Siberia has a great reserve of forests. It has a forest area two and one-half times that of the European portion of the Soviet Union. So great are Siberia's forest resources that about 6 billion cubic feet of softwood timber a year could be exported and the domestic consumption increased to about 4 billion cubic feet without depleting the resource. When compared with the world's present exports of timber, Siberia's possibilities for trade and exchange in forest products are enormous but limited by the cost of making the timber available.

Sweden, for its size, is one of the richest countries of the world in timber and, with the exception of Finland, has the highest percentage of forested area in Europe. The soil and climate are particularly well adapted to forest growth. Sweden not only exports much timber, but her forests also supply important home industries with lumber and wood pulp.

A thousand species of trees, many of which yield excellent timber, grow unusually well in Japan because of the favorable climate, especially plentiful moisture. More than one-half of the total land area of Japan is productive forest land. The comparatively large proportion of forest land is the combined result of mountainous areas unfit for cultivation, the difficulty of transportation, and the State policy of protection and reforestation. Japan's lumber exports are many times her imports. Other exports of forest products include charcoal, camphor and camphor oil, bamboo, vegetable wax, bamboo ware, and woodenware. The average annual cut per acre is little more than seven-eighths of the average annual growth; hence, Japan is on a sustained-yield basis.

Great Britain, with a very small area of forests of her own, must depend almost entirely on imported raw materials, about one-eighth from her colonies and about seven-eighths from foreign countries, much of it coming from the Soviet Union and Sweden.

FIGURE 18.-Where forests will grow, not where they still are. Even though there are still vast forest areas on other continents from which wood could be secured, why does the citizen of this country need forests at home?

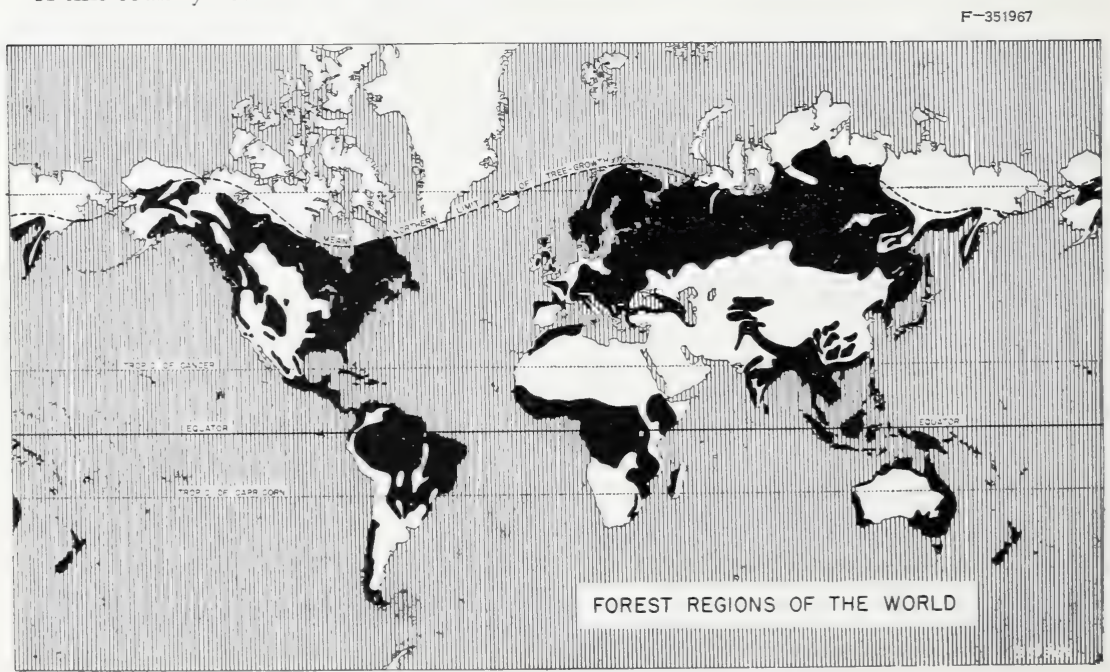


Germany, although making the most of her own forest resources, imports large quantities of lumber from northern and eastern Europe; longleaf pine, Douglas fir, cedar, and hardwood timbers from the United States; oak from Japan; and jarrah, teak, cabinet woods, and dyewoods from the Tropics.

Italy, with a low productivity and undeveloped wood-using industries, meets her needs for wood by imports from abroad.

\section{How Can Forests be Used and Maintained?}

Mine or crop?-When all the gold is removed from a mine, there will never be any more there. When the timber has been cut from a forest, more timber will grow if seed trees are left and fire is kept out of the cutover land.

Gold is a nonrenewable resource. Forests are a renewable resource, and therefore should be treated as a crop. Crops are grown for use. Use gives value to forests. If use and value are to be maintained, forests must be properly managed.

Reforestation needed.-Forests have the power to spread and renew themselves if conditions are right. These conditions even permit cutting most of the trees. Only in a few kinds of forest will there be a new growth of the same kind unless some trees are left. All kinds of forests are kept from renewing themselves if they are burned severely or repeatedly. This is especially true if all the trees have been cut, and the land is burned over.

Much land from which the forest has been cut is unproductive for farm crops. In fact, some of it is a liability unless it is covered with forest growth. These conditions make it man's responsibility to provide for reforestation of such land. It is necessary in some cases to plant trees of a valuable kind on cut-over land where otherwise worthless weed trees would occupy the land. In other cases, it is necessary to plant trees to hasten the growth of a protective cover to keep the soil from washing or blowing away.

Two methods of reforestation are possible-artificial or natural. A lumberman may clear-cut his holdings, removing all the mature trees at one time, then replant with young trees. That is artificial reforestation. On the other hand, he may remove the mature trees in several cuttings. Each time he will take only part of the timber, thus taking advantage of the seed produced by the remaining trees to grow a new forest. Periods of from 5 to 40 years may elapse between cuts. In such harvesting, which is known as selective logging, the smaller, more thrifty trees are left each time. After the large mature and overmature timber has been cut, the vigorous trees usually grow at a more rapid rate. The remaining stand also functions very well in protecting the seedlings and saplings which fill in the openings caused by the cutting. That is natural reforestation.

The decision as to which method of reforestation to use must be made by expert foresters who have carefully studied the problem. Where it is possible the natural reforestation method is cheaper because lumber production is continuous and water, soil, wildlife, and recreation values are least disturbed. But much land has been left without any provision for natural seeding and so must be planted. The extent of the task is shown partly by the 131,707 acres in national forests planted in 1939. Up to Jan. 1, 1940, the total area of plantations on the national forests amounted to 946,574 acres. The Civilian Conservation Corps has made extensive 
reforestation possible. The Forest Service estimates that 31/2 million acres on national forests are in need of immediate planting in order to bring the land into production of timber, to protect watersheds, and yield other returns to the public.

Protection from fire.-Despite widespread efforts to protect forest resources many million acres are burned over each year. Land that has been logged is likely to burn over because of the large amount of slash that is left. This slash is composed of branches, tree tops, and damaged portions of the trunks. When not lopped, that is, cut in small pieces that will lie close to the ground and absorb moisture, it dries out and will catch fire easily. It takes money to hire men to lop this slash and for that reason it is very often left as it falls when the logs are cut. It is the burning of this accumulated dry brush, leaves, and weeds left after logging that keeps the forest from growing again.

Some people think nothing is lost where no large trees are burned, but young trees are often killed by a fire that would do little harm to an old tree. The young tree is important for the future forest and so has a value. Most often forest fires are started by someone who is thoughtless and does not realize either the danger or the loss.

Nine out of every ten fires are man-made (table 7, p. 45). Smoking, camping, debris burning, logging operations, and lightning are among the chief causes of forest fires. In a recent 5-year period 7.6 percent of all fires recorded were caused by lightning, and the remaining 92.4 percent were man-caused. Most of the lightning fires occur in the higher areas of the West in seasons of drought.

Protection for the attractiveness of the forest.-Being careful in the cutting of decorative greens is one way to protect the forest. It is not necessary to go without or even reduce our use of these materials, but they must be harvested in such a way that the trees or roots that provide them are not destroyed. Particularly is this true when gathering ground pine, holly, ferns, or other decorative plants. Picking up all papers and debris left from a picnic or after camping is also important forest protection.

Protection from insects and diseases. - The Federal Government guards constantly against importation of trees diseases and damaging insects from other countries. These small and often invisible foes may ruin great sections of forests before their presence is discovered. Insects and diseases work in forests in many different ways. Although many forms of both are usually present in any normal forest, damage is usually rather limited. When, however, either insects or diseases suddenly build up to epidemic proportions, prompt action must be taken to control them and thus to prevent widespread destruction. Disease and insect control is often neglected on privately owned forests because of the great cost involved in protection, and for this reason protection of adjoining publicly owned forests is sometimes futile.

Protection by proper cutting.- Harvesting of the mature crop, if carelessly done, may result in the ruin of a forest by so cutting the big trees that they are permitted to break down the little ones; by not leaving seed trees to reproduce the stand for the next crop; by taking all the good species of trees and leaving the worthless kinds to take possession of the land; by using heavy logging machinery that smashes down the young timber; by leaving a tangle of brush and broken trees to form a fire trap and encourage total destruction of the forest cover by fire; by leaving diseased and insect-infested trees in the woods to spread the infection to healthy young stands. The 
forester must use the harvesting of the mature crop as an opportunity to get rid of the overmature, diseased, and inferior trees, and to reserve for the next crop the young vigorous trees of the most valuable species.

Cooperation in protection needed.-One might assume that privately owned forests would have better protection than those publicly owned, but this is often not the case. Forest protection costs money and many owners do not feel they can afford it. Others are forced by financial circumstances to get an immediate cash return and cannot manage their forest land for future benefits and profits. Often in such instances, all seed trees are removed, the new growth is not protected, the immature trees are cut along with mature trees, and fire is allowed to destroy the young growth and the soil. The public benefits from forests justify State and Federal Governments helping forest owners protect forest lands.

Forests in abundance.-With forests managed as foresters know how, neither this nor future generations need deny themselves any of the benefits of living in forest lands.

\section{Things to do:}

\section{Leads to Furtber Study}

1. Make maps of the United States showing: (a) Main forest regions; (b) main river systems whose headwaters are in the forests; (c) comparison of forest areas in 1620 and the present; (d) comparison of forest areas and areas of heaviest rainfall.

2. Make graphs showing lumber production and consumption expressed in board feet or value in dollars: (a) By countries, ( $b$ ) by States, ( $c$ ) by years, $(d)$ by species of tree, $(e)$ per capita.

Make similar graphs for pulpwood production and consumption.

3. Make graphs showing: (a) Forest acreage by States or countries; (b) commercial and noncommercial forest in the United States; (c) Federal, State, and private ownership of forest lands by States or countries; (d) exports and imports by countries; (e) interstate forest commerce in the United States; $(f)$ value of different wood species in United States.

4. Make a relief map of the United States by using the salt and flour mixture of papier-mâché. (Paper towels, torn up, boiled, and stirred well with a little starch added will serve as a substitute for papier-mâché. You will have to experiment with it.) Color coniferous forest areas dark green, hardwood areas a lighter green, and mixed areas mottled, snowcapped mountains white, rivers and lakes blue, principal forest-industrial cities black, aqueducts for city-water supply broken blue lines. In discussing the map bring out such points as: The main rivers rise in the forests, and the dependence of cities such as Portland, Oreg., on the lumber industry, and Los Angeles and New York on forests for their water supply.

5. Make jigsaw puzzle maps of the United States cut on lines of forest regions (figs. 2 and 6 ).

6. Make flash cards on some of the text questions.

7. Make word puzzles such as the following: A six-letter word meaning a community of trees. Answer: Forest.

8. Secure a piece of hardwood and a piece of softwood and compare their weights (density), and ease with which they may be cut, dented, and split.

9. List as many uses of the forest as you can find. Divide the list into two parts, one being the uses of wood and the other the uses of the standing forest. 
10. Discuss whether (a) the forest is more important for watershed protection or for our lumber supply; (b) recreation areas in the forest are more important than pulpwood-producing areas; (c) wildlife management should be an important part of forest management; (d) farm woodlands are profitable to the Corn Belt farmer.

11. List the forest industries that depend directly on the forest for raw materials.

12. Visit as many wood-using industries in the community as possible and find out where they get their raw materials and how these are transported. Find out where their products are used and how transported. Find out how many people are employed at each place visited.

13. Find out where your local supplies of construction lumber come from. Trace the route on the map.

14. Find out from an electric or telephone company what kinds of trees are used for telephone, telegraph, and electric-line poles, where they grew, how they are transported to your community.

15. Find out what these words mean: Forest, coniferous, deciduous, altitude, timber, board foot, watershed, national forest, hardwood, softwood, erosion, pulpwood, wood pulp, resin, rosin, piling, veneer, naval stores, plastics, primary forest industries, sawlog, veneer log, cut-over land, cordwood, chaparral, timber line, reforestation, afforestation, exploitation.

16. Find out what precautions are taken to prevent importing forest insects and disease when importing lumber and forest products.

17. Point out on a world map the international exchange of forest products.

18. Make an extensive exhibit of forest products. This will take some research because it is not generally known that often combs, fountain pens, some clothes and rugs, are made from wood. Write to your regional forester, at address under which your State is listed, and ask for a copy of Wood-The Material Of A Thousand Uses.

Federal Building, Missoula, Mont.; Montana, northeastern Washington, northern Idaho, and northwestern South Dakota.

Post Office Building, Denver, Colo.; Colorado, Kansas, Nebraska, South Dakota, and most of Wyoming.

Post Office Building, Albuquerque, N. Mex.; Arizona and New Mexico.

Forest Service Building, Ogden, Utah; Utah, southern Idaho, western Wyoming, and Nevada.

760 Market Street, San Francisco, Calif.; California and southwestern Nevada.

Post Office Building, Portland, Oreg.; Washington and Oregon.

Victor Building, Washington, D. C.; Connecticut, Delaware, Kentucky, Maine, Maryland, Massachusetts, New Hampshire, New Jersey, New York, Pennsylvania, Rhode Island, Vermont, Virginia, and West Virginia.

Glenn Building, Atlanta, Ga.; Alabama, Arkansas, Florida, Georgia, Louisiana, Mississippi, North Carolina, Oklahoma, Puerto Rico, South Carolina, Tennessee, and Texas.

Plankinton Building, Milwaukee, Wisc.; Illinois, Indiana, Iowa, Michigan, Minnesota, Missouri, North Dakota, Ohio, and Wisconsin.

Federal and Territorial Building, Juneau, Alaska; Alaska.

19. Find out all you can about the making of baseball bats, skiis, violins, hockey clubs, wood plastics, veneer.

20. Make a list of recreational activities which people may enjoy in the forest.

21. Tell how you would give a friendly warning to a companion who was not being careful with fire in the woods.

22. Develop a simple pageant to show the different influences of forests on man's activities. Divide into four episodes-primitive man dominated by the forest, man conquering the forest, man destroying the forest, and man conserving the forest. 
23. Find out from your county or State planning board the condition and importance of the forests in the county or State.

24. Compare a forest with a mine and with a farm.

25. Find out how a farmer may secure State and Federal assistance in protecting his forests from fire.

26. Organize, in forest areas, groups to cooperate with forest rangers in locating and reporting forest fires. Such groups may participate in giving tourists fire-prevention information and assist in other ways in controlling fire.

27. Discuss the following from a poem by Henry Van Dyke:
Many a tree is found in the wood,
And every tree for its use is good;
Some for the strength of the gnarled root,
Some for the sweetness of flower and fruit;
Some for a shelter against the storm,
And some to keep the hearthstone warm,
Some for the roof, and some for the beam,
And some for the boat to breast the stream.
In the wealth of the wood since the world began,
The trees have offered their gifts to man.

\section{Questions for discussion.}

1. Are hardwoods or softwoods used more extensively for building houses? For making furniture? Why? What other uses are there for each of these two types of lumber?

2. How are the conifers better adapted to colder, drier climates than the broadleaf trees? Consider size, shape, and kind of leaf in respect to evaporation of water and damage from snow.

3. How may we know what kinds of trees to plant near our homes? In a school or community forest?

4. In what ways are food-distributing companies dependent upon the forest?

5. Why is less wood used for fuel in this country than in Europe? Why are we likely not aware of the great value of wood used for fuel?

6. In what way do forests help in supplying (a) water, (b) illumination, (c) communication?

7. Which do you think is the more important to railroads, the use of wood in construction of cars and tracks or the revenue from carrying forest products? Why?

8. Why was chestnut one of the favorite woods for railroad ties and why is it now seldom used?

9. How do woodlands and windbreaks help the farmer?

10. Is it true that every American industry depends upon the forest because of its need for lumber? Give your reasons.

11. What three reasons can you give to show why it is important for paper-making industries to be located in forest regions?

12. For what uses has wood been partly replaced and for what new purposes is wood now used?

13. How did the forest hinder and how did it help agriculture in this country in pioneer days? Why is forestry now considered a form of agriculture?

14. Why does the United States export and also import wood?

15. Why is the United States the greatest wood-using country in the world?

16. Why is the greatest trade and exchange in forest products between Europe and North America? 
17. Why are tropical hardwoods so little used in comparison to temperate hardwoods?

18. Why can Japan export while China has to import forest products?

19. What effect does proper management of forests have on wood-using industries? On employment? Why?

20. What is the difference between a forest and a park? How are they similar?

21. Which is usually managed more carefully-publicly or privately owned forests? Give reasons.

22. What is the cause of most of our forest fires?

23. What responsibility should each person assume in regard to forest-fire protection?

24. What protection does the forest need other than fire protection?

25. Why is it important to carry on a program of wildlife management in forest areas? Under what conditions are hunting and fishing urged? Under what conditions prohibited?

26. Why is it advisable to develop field windbreaks in certain treeless farming areas?

27. How do forests aid in soil formation, in erosion control, and in flood control?

28. What is the greatest value of the forests nearest your home?

29. Do you expect that more or less of the total area of the United States will be forested 25 years hence? Why?

30. Why are the most extensive national forests in the West? Why were forest lands purchased by the Federal Government for national forests in the East?

\section{Problems of Interest.}

1. It is estimated that $31,265,625$ cords of wood are used annually as fuel in the United States. If piled 4 feet high and to completely cover the ground, how many square miles would this cover?

2. Find what percentage the number of people directly employed in forest industries in the United States is of the population of your State or the biggest city in your State.

\section{Informative tests.}

Selection: Which of the following does the group consider the best statement of what should be done to conserve forests? (No. 4 should be selected.)

1. We should use less wood and wood products.

2. We should import more wood and wood products and save our own forests.

3. No timber should be cut on publicly owned forest land, only on private lands.

4. All timber should be cut and other forest uses so carried on as to provide for continued use.

5. All that needs to be done is to cut down on the great waste of wood in logging and at sawmills.

True or false: Place $X$ in blank if statement is true, $O$ if statement is false.

$X \quad$ 1. The United States is the second greatest lumber-producing and wood-using country in the world.

$X \quad 2$. Sustained-yield management means keeping the forest productive by proper care and protection. 
3. It is necessary to use wood substitutes to protect our forests.

4. The United States imports wood in order to save the forests in this country.

5. At least 20 industries are directly dependent upon the forest for raw materials.

X 6. More than 90 percent of all forest fires are caused by human activities.

7. National forests are made up mainly of stands of virgin timber.

8. All timber cutting on national forests is done in such a way that the forest will remain productive.

9. Wildlife management is important in forest management.

$\frac{x}{0}$

10. Field tree windbreaks, once they are established, will change the climate of a region.

$X$ 11. Ordinarily publicly owned forests have better protection and management than privately owned forests.

Completion: The following sentences are given to the study group with the italicized words omitted, and they are asked to insert the proper words in the blank spaces. The words in italic are, of course, the proper ones for completion of the sentences.

1. Forested watersheds aid navigation by keeping channels free from silt.

2. Next to lumber the most commonly used forest product is fuel.

3. Oak, walnut, maple, are most commonly used as furniture woods in the United States.

4. Rosin is now used principally in the manufacture of paper, soap, and varnish.

5. Paper making is increasing the demand for wood faster than it is being replaced in the older chemical industries.

6. The principal wood-exporting countries of Europe are Sweden, the Soviet Union, and Finland.

7. Windbreaks check wind velocity for some distance to leeward.

8. In 1620 about one-half of the land of the United States was forested; today about one-third is classed as forest land although much of it is in a devastated condition.

9. The Soviet Union has the most extensive forests, having more than onefifth of the world's forests, and is the greatest wood-exporting country.

10. Brazil is the outstanding forest country of South America.

Multiple choice.-Underline the proper term in ( ).

1. The main farm forests are in the (East, Middle West, Pacific Northwest).

2. The farm forest crop is ranked (fourth, ninth, twentieth) among other farm crops.

3. Farm woodlands in the Great Plains are most useful for (fuel, grazing areas, windbreaks).

4. Eighty-five percent of the paper is now made from (flax, cotton, wood).

5. The newest wood use is for (cellophane, rayon, plastics).

6. The United States imports wood mostly for (building, furniture, paper).

7. Most people per acre are employed in the forests of (United States, Denmark, England).

8. The use of forests for recreation is (increasing, decreasing, remaining about the same). 
9. A common practice under private ownership has been (to reforest, to leave seed trees, to abandon) land after logging.

10. About 95 percent of the coniferous forests of the world are in the (Torrid, South Temperate, North Temperate) Zone.

Matching to show correct relation.-Letters from the first column are to be placed in parentheses of the second column to show the correct relation. Here the letters have been inserted in their right places. In use, of course, the lists should be given to the group with the spaces in second column blank.

1. Forest regions of United States:

a. Northeast............ (c) Yellow pine, cypress.

b. Central hardwood...... (a) White pine, fir, and spruce.

c. Southern............ (d) Ponderosa pine.

d. Rocky Mountain...... (b) Oaks, hickories, walnut, poplars.

2. Countries:

e. Pacific coast........... (e) Douglas fir, redwood.

a. Finland.

Forest character

(c) One of richest in timber and second highest in Europe in percentage of area in forest.

b. Siberia.............. (a) Nearly one-half of the total area is productive forest.

c. Sweden Has the greatest reserve of forests.

d. Great Britain.......... (d) Must depend almost entirely on imports. 


\section{Statistical Tables for Reference Use}

$\mathrm{T}_{\mathrm{ABLE}}$ 1.- Some very general differences between the two great classes of trees

\begin{tabular}{|c|c|c|}
\hline Points of comparison & Coniferous & Broadleaf \\
\hline $\begin{array}{l}\text { Kind of leaves } \\
\text { Leaf retention } \\
\text { Seeds borne }\end{array}$ & $\begin{array}{l}\text { Scale or needlelike } \\
\text { Held year round-evergreen } \\
\text { In cones. (A few have modified } \\
\text { cones that appear as berries.) }\end{array}$ & $\begin{array}{l}\text { Broad. } \\
\text { Drop in autumn-deciduous. } \\
\text { As fleshy fruits, berries, nuts. }\end{array}$ \\
\hline $\begin{array}{l}\text { Site conditions to which adapted. } \\
\text { Nature of wood.................... }\end{array}$ & $\begin{array}{l}\text { Will grow on poor soils in dry, cold } \\
\text { regions; high altitudes; and on } \\
\text { north slopes. } \\
\text { Softwood (less dense) }\end{array}$ & $\begin{array}{l}\text { Require good soils; humid, warm } \\
\text { regions; low altitudes; south } \\
\text { slopes. } \\
\text { Hardwood (more dense). }\end{array}$ \\
\hline
\end{tabular}

ESTIMATED RELATIVE ANNUAL VALUE OF FOREST PRODUCTS AT POINT OF UTILIZATION OR DISTRIBUTION ${ }^{1}$

Logs for lumber and orher sawed products .................... $\$ 300,000,000$

Fuel wood . . . . . . . . . . . . . . . . . . . . . . . . . . . . . . . . . . . . . . .

Fence posts. . . . . . . . . . . . . . .

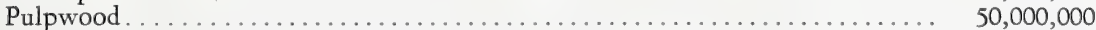

Veneer logs ........................................ 20,000,000

Hewed ties............................................ 18,000,000

Poles............................................... 10,000,000

Piling .......................................... $4,000,000$

Distillation wood . . . . . . . . . $3,000,000$

Naval stores.................................... 40,000,000

Tanning materials ........................................ 10,000,000

Nuts .................................................... 10,000,000

Maple sirup and sugar ................................ $5,000,000$

Christmas trees and greenery .............................. 2,000,000

Pharmaceuticals and oils . . . . .

Total values

$793,500,000$

${ }_{1}$ Figures from U. S. Department of Agriculture, Products of American Forests, Unnumbered Pub., 1939.

TABLE 2.-Lumber production, exports, imports, and consumption, 1910-37

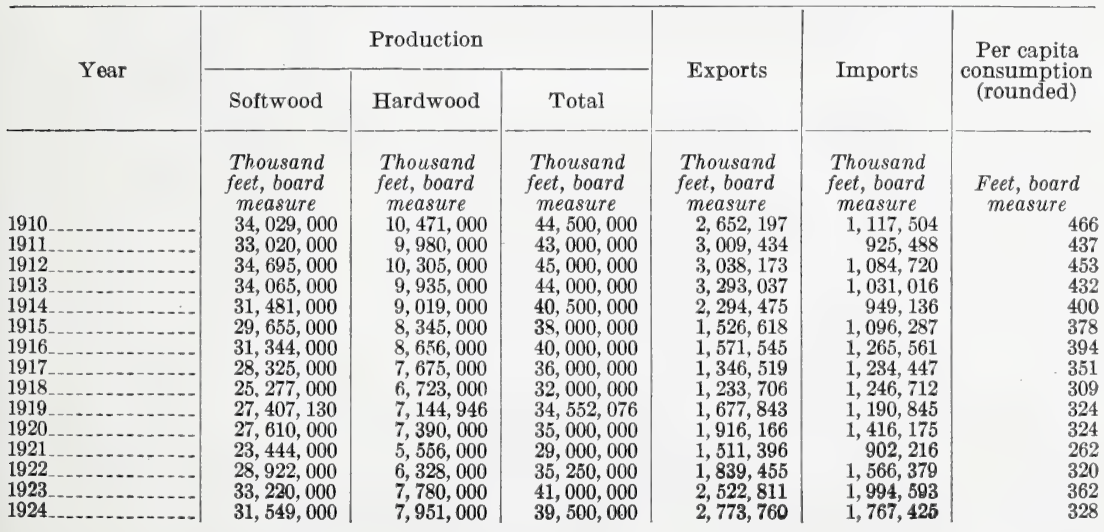


TABLE 2.-Lumber production, exports, imports, and consumption, 1910-37-Continued

\begin{tabular}{|c|c|c|c|c|c|c|}
\hline \multirow{2}{*}{ Year } & \multicolumn{3}{|c|}{ Production } & \multirow{2}{*}{ Exports } & \multirow{2}{*}{ Imports } & \multirow{2}{*}{$\begin{array}{l}\text { Per capita } \\
\text { consumption } \\
\text { (rounded) }\end{array}$} \\
\hline & Softwood & Hardwood & Total & & & \\
\hline $\begin{array}{l}1925 \\
1926 \\
1927 \\
1928 \\
19290 \\
1931 \\
1932 \\
1933 \\
1934 \\
1936 \\
1937\end{array}$ & $\begin{array}{c}\text { Thousand } \\
\text { feet, board } \\
\text { measure } \\
33,284,000 \\
32,078,000 \\
29,975,000 \\
29,852,000 \\
29,813,345 \\
21,322,786 \\
13,851,951 \\
8,745,636 \\
11,898,873 \\
12,735,358 \\
16,247,981 \\
20,241,731 \\
21,589,123\end{array}$ & $\begin{array}{c}\text { Thousand } \\
\text { feet, board } \\
\text { measure } \\
7,716,000 \\
7,672,000 \\
7,275,000 \\
6,898,000 \\
7,072,687 \\
4,728,687 \\
2,670,692 \\
1,405,596 \\
2,062,261 \\
2,758,281 \\
3,290,750 \\
4,113,153 \\
4,407,734\end{array}$ & $\begin{array}{c}\text { Thousand } \\
\text { feet, board } \\
\text { measure } \\
41,000,000 \\
39,750,000 \\
37,250,000 \\
36,750,000 \\
36,886,032 \\
26,051,473 \\
16,522,643 \\
10,151,226 \\
13,961,134 \\
15,493,639 \\
19,538,731 \\
24,354,884 \\
25,996,857\end{array}$ & $\begin{array}{c}\text { Thousand } \\
\text { feet, board } \\
\text { measure } \\
2,648,023 \\
2,956,902 \\
3,181,590 \\
3,522,400 \\
3,364,470 \\
2,410,207 \\
1,770,058 \\
1,197,283 \\
1,348,857 \\
1,460,790 \\
1,405,065 \\
1,515,318 \\
1,526,000\end{array}$ & $\begin{array}{r}\text { Thousand } \\
\text { feet, board } \\
\text { measure } \\
1,875,101 \\
1,932,862 \\
1,781,116 \\
1,493,448 \\
1,570,082 \\
1,240,120 \\
758,454 \\
391,913 \\
367,915 \\
296,563 \\
443,176 \\
670,664 \\
698,000\end{array}$ & $\begin{array}{l}\text { Feet, board } \\
\text { measure } \\
343 \\
327 \\
300 \\
295 \\
274 \\
190 \\
144 \\
94 \\
116 \\
114 \\
146 \\
184 \\
187\end{array}$ \\
\hline
\end{tabular}

Forest Service compilation based on reports of the Bureau of the Census and the Bureau of Foreign and Domestic Commerce.

TABLE 3.- Lumber consumed in fabricated products and by wood-using industries, 1912, 1928, and 19331

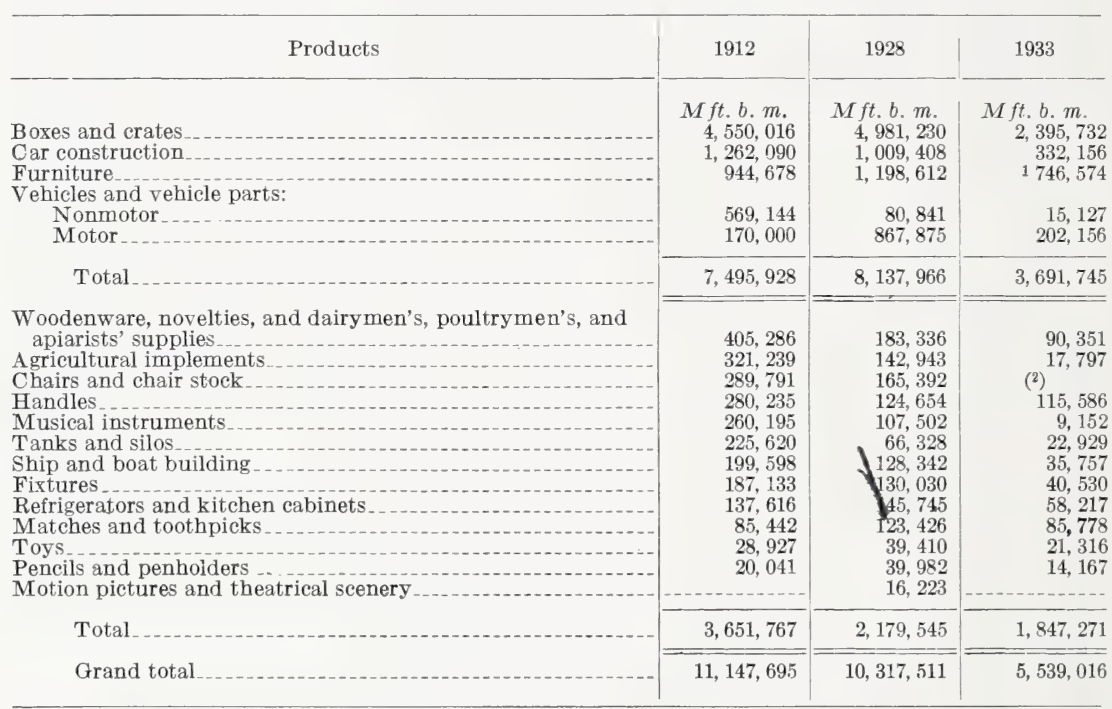

${ }_{1}$ Includes chairs and chair stock.

2 Figures for 1933 included under furniture.

Forest Service compilation. 


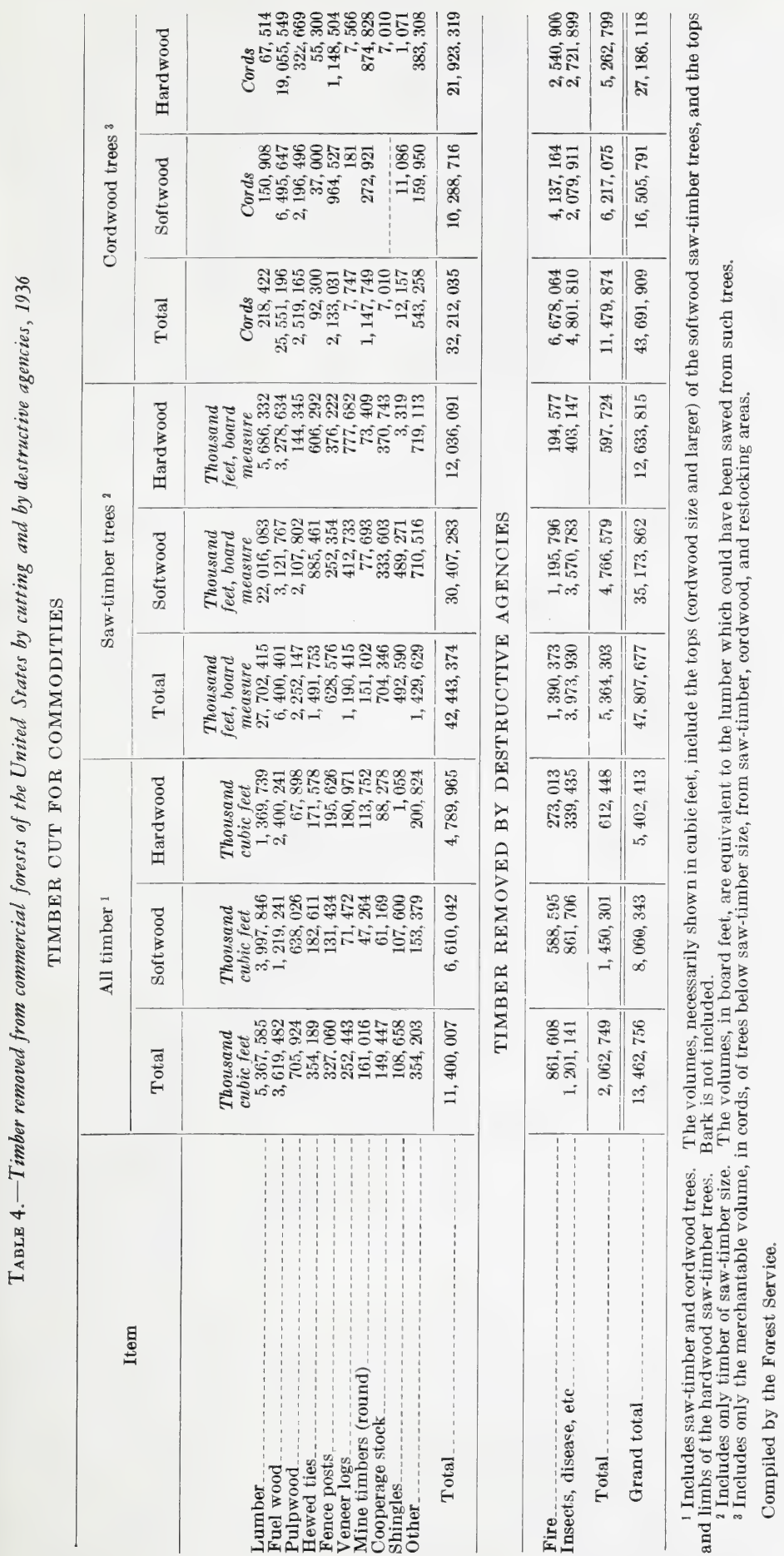


TABLE 5.-Current annual growth and drain, 1936

\begin{tabular}{|c|c|c|c|c|c|c|c|}
\hline \multirow[b]{2}{*}{ Region } & \multicolumn{3}{|c|}{ Saw timber and cordwood } & \multicolumn{4}{|c|}{ Saw timber } \\
\hline & Growth & Drain & $\begin{array}{l}\text { Ratio, } \\
\text { drain to } \\
\text { growth }\end{array}$ & Growth & Drain & $\begin{array}{l}\text { Ratio, } \\
\text { drain to } \\
\text { growth }\end{array}$ & $\begin{array}{l}\text { Saw tim. } \\
\text { ber cut } \\
\text { for } \\
\text { lumber }\end{array}$ \\
\hline $\begin{array}{l}\text { Northeastern } \\
\text { Central } \\
\text { Lake }\end{array}$ & $\begin{array}{r}\text { Million } \\
\text { cubic feet } \\
1,260 \\
568 \\
979\end{array}$ & $\begin{array}{r}\text { Million } \\
\text { cubic feet } \\
1,370 \\
907 \\
983\end{array}$ & $\begin{array}{l}1.1 \\
1.6 \\
1.0\end{array}$ & $\begin{array}{r}\text { Million } \\
\text { feet board } \\
\text { measure } \\
2,625 \\
978 \\
1,850\end{array}$ & $\begin{array}{r}\text { Million } \\
\text { feet board } \\
\text { measure } \\
2,468 \\
1,781 \\
2,420\end{array}$ & $\begin{array}{l}0.9 \\
1.8 \\
1.3\end{array}$ & $\begin{array}{r}\text { Million } \\
\text { feet board } \\
\text { measure } \\
978 \\
469 \\
1,307\end{array}$ \\
\hline $\begin{array}{l}\text { South: } \\
\text { Coastal Plain } \\
\text { Piedmont } \\
\text { Mountain } \\
\text { Delta. } \\
\text { Pine-hardwoods-west }\end{array}$ & $\begin{array}{r}1,626 \\
2,143 \\
893 \\
478 \\
1,355\end{array}$ & $\begin{array}{r}1,691 \\
1,812 \\
1,487 \\
573 \\
1,126\end{array}$ & $\begin{array}{r}1.0 \\
.8 \\
1.7 \\
1.2 \\
.8\end{array}$ & $\begin{array}{l}5,645 \\
6,841 \\
1,810 \\
1,278 \\
4,829\end{array}$ & $\begin{array}{l}6,705 \\
6,550 \\
3,908 \\
1,846 \\
4,633\end{array}$ & $\begin{array}{l}1.2 \\
1.0 \\
2.2 \\
1.4 \\
1.0\end{array}$ & $\begin{array}{r}3,532 \\
4,128 \\
1,723 \\
964 \\
2,930\end{array}$ \\
\hline Total $\ldots \ldots$ & 6,495 & 6,689 & 1. 0 & 20,403 & 23,642 & 1. 2 & 13,277 \\
\hline $\begin{array}{l}\text { Columbia River Basin: } \\
\text { West coast } \\
\text { Interior }\end{array}$ & $\begin{array}{l}917 \\
717\end{array}$ & $\begin{array}{l}1,833 \\
1,016\end{array}$ & $\begin{array}{l}2.0 \\
1.4\end{array}$ & $\begin{array}{l}2,739 \\
2,508\end{array}$ & $\begin{array}{l}9,550 \\
4,714\end{array}$ & $\begin{array}{l}3.5 \\
1.9\end{array}$ & $\begin{array}{l}6,772 \\
2,831\end{array}$ \\
\hline Total $\ldots$ & 1,634 & 2,849 & 1.7 & 5,247 & 14,264 & 2.7 & 9,603 \\
\hline $\begin{array}{l}\text { California } \\
\text { South Rocky Mountain } \\
\text { Plains }\end{array}$ & $\begin{array}{l}155 \\
196\end{array}$ & $\begin{array}{r}501 \\
164 \\
\end{array}$ & $\begin{array}{r}3.2 \\
.8 \\
-\end{array}$ & $\begin{array}{r}414 \\
516\end{array}$ & $\begin{array}{r}2,649 \\
584\end{array}$ & $\begin{array}{l}6.4 \\
1.1\end{array}$ & $\begin{array}{r}1,647 \\
422 \\
-\end{array}$ \\
\hline All regions . . . . & 11,287 & 13,463 & 1. 2 & 32,033 & 47,808 & 1. 5 & 27,703 \\
\hline
\end{tabular}

Compiled by the Division of Forest Economics, Forest Service.

$\mathrm{T}_{\mathrm{ABLE}}$ 6.-Per capita annual timber consumption in European countries, 1913 and 1928-29 (in equivalents of standing timber)

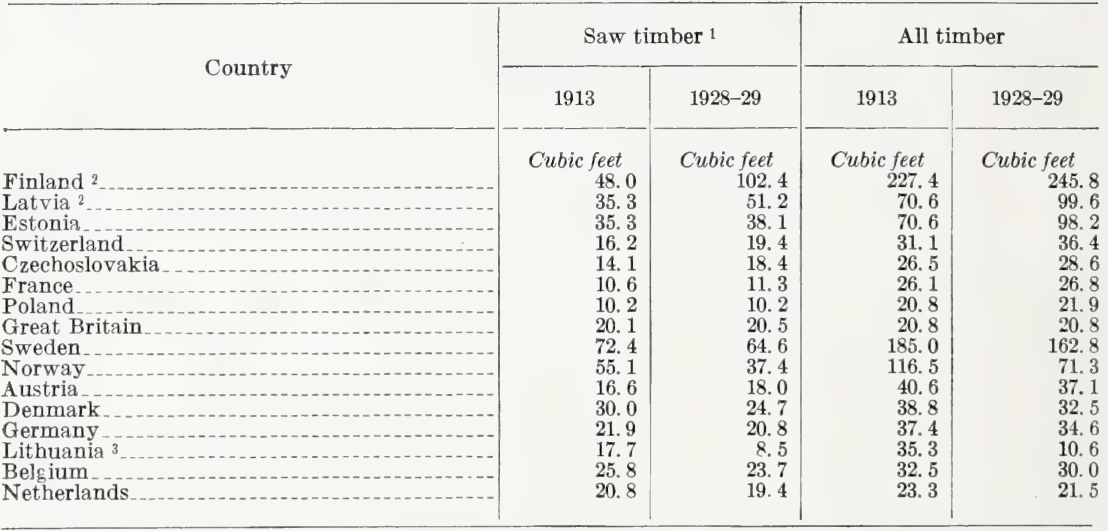

1 Saw timber includes all classes of wood except firewood.

2 Large apparent increase in saw-timber consumption in Finland explained by better statistics in 1928-29. Part of increase in Latvia also results from better statistics.

3 Abnormally low consumption in 1928-29 due to disturbed conditions. 
United States . . . . . . . . . . . . . . . . . . . . . . . . . . . . 121

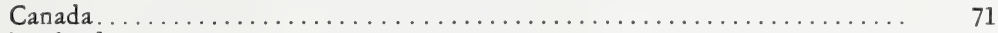

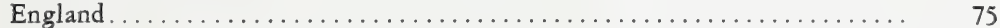

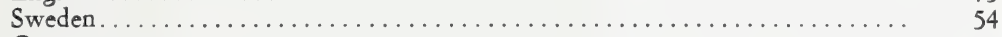

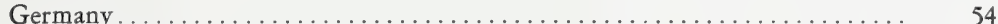

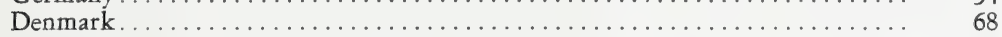

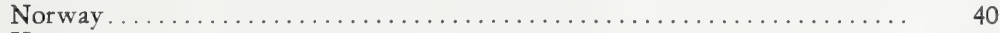

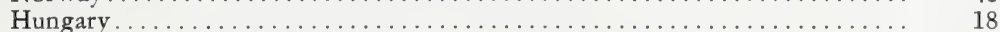

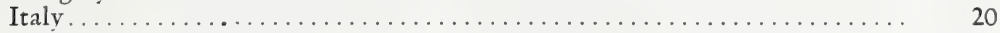

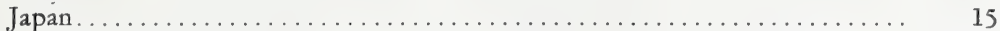

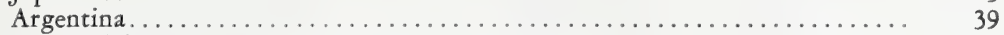

Soviet Union. . . . . . . . . . . . . . . . . . . . . . . . . . . . . 7

Data from La Foret, Le Papier, Le Journal, Paris, 1936.

TABLE 7.- Average number of fires by cause, national forests, State, and private lands (protected areas only), 1933-37

\begin{tabular}{|c|c|c|c|c|c|}
\hline Cause & Number & Percent & Cause & Number & Percent \\
\hline $\begin{array}{l}\text { Smokers } \\
\text { Lightning } \\
\text { Railroads } \\
\text { Campers } \\
\text { Debris burning } \\
\text { Incendiary }\end{array}$ & $\begin{array}{r}16,282 \\
5,813 \\
2,901 \\
4,175 \\
9,126 \\
16,487\end{array}$ & $\begin{array}{r}24.4 \\
8.7 \\
4.3 \\
6.3 \\
13.7 \\
24.7\end{array}$ & $\begin{array}{l}\text { Lumbering } \\
\text { Miscellaneous } \\
\text { Unknown } \\
\text { Man-caused } 1 \text { - } \\
\text { All causes. }\end{array}$ & $\begin{array}{c}1,207 \\
5,964 \\
4,797 \\
66,752\end{array}$ & $\begin{array}{r}1.8 \\
8.9 \\
7.2 \\
91.3 \\
\end{array}$ \\
\hline
\end{tabular}

1 The figure given here assumes that all fires starting from miscellaneous or unknown causes were the result of human activities. 




